Human Capital and Growth:

Specification Matters

Uwe Sunde, Thomas Vischer

August 2011 Discussion Paper no. 2011-31 


$\begin{array}{ll}\text { Editor: } & \text { Martina Flockerzi } \\ & \text { University of St. Gallen } \\ & \text { School of Economics and Political Science } \\ & \text { Department of Economics } \\ & \text { Varnbüelstrasse } 19 \\ & \text { CH-9000 St. Gallen } \\ & \text { Phone } \quad+41712242325 \\ & \text { Fax } \quad+41712243135 \\ & \text { Email seps@unisg.ch } \\ & \text { School of Economics and Political Science } \\ & \text { Department of Economics } \\ & \text { University of St. Gallen } \\ & \text { Varnbüelstrasse 19 } \\ \text { Publisher: } & \text { CH-9000 St. Gallen } \\ & \text { Phone +41 71 224 23 25 } \\ & \text { Fax } \quad+41712243135 \\ & \text { http://www.seps.unisg.ch }\end{array}$




\title{
Human Capital and Growth: Specification Matters
}

\author{
Uwe Sunde ${ }^{1}$, Thomas Vischer
}

Author's address:

Uwe Sunde

University of St.Gallen

Swiss Institute for Empirical Economic Research (SEW-HSG)

Varnbüelstrasse 14

$\mathrm{CH}-9000$ St. Gallen

Email Uwe.Sunde@unisg.ch

Thomas Vischer

University of St.Gallen

Swiss Institute for Empirical Economic Research (SEW-HSG)

Varnbüelstrasse 14

$\mathrm{CH}-9000$ St. Gallen

Email Thomas.Vischer@unisg.ch

\footnotetext{
${ }^{1}$ University of St. Gallen, IZA Bonn, and CEPR, London.
} 


\begin{abstract}
This paper suggests that the weak empirical effect of human capital on growth in existing cross-country studies is partly the result of an inappropriate specification that does not account for the different channels through which human capital aspects growth. A systematic replication of earlier results from the literature shows that both, initial levels and changes in human capital, have positive growth effects, while in isolation, each channel often appears insignificant. Studies that do not account for both channels might underestimate the effect of human capital due to convergence in human capital, in particular when measuring human capital in log average years of schooling. This study therefore complements alternative explanations for the weak growth effects of human capital based on outlier observations and measurement issues.
\end{abstract}

\title{
Keywords
}

Human Capital, Growth Regressions, Specification.

\section{JEL Classification}

O47, O11, O15, E24. 
Despite the conventional view that human capital is one of the main determinants of growth, the evidence for the effect of human capital on growth is weak and controversial. While studies since Mankiw, Romer, and Weil (1992) and Benhabib and Spiegel (1994) found significant positive effects of human capital (e.g., in terms of years of schooling) on income levels, the findings regarding the growth effect have been rather contradictory. For instance, Mankiw et al. (1992) reported a positive effect of human capital on growth in a human capital augmented Solow (1956) framework, whereas Benhabib and Spiegel (1994) found no effect in a growth accounting exercise and suggested instead a different specification with human capital affecting growth through productivity. These contradictory findings have given rise to a lengthy debate about the growth effects of human capital in the literature. Several explanations have been suggested, including the role of outlier observations (Temple, 1999), the way human capital is measured in terms of quantity or quality (Barro, 2001, Hanushek and Woessmann, 2008), data quality of human capital measures (de la Fuente and Domenech, 2006, Cohen and Soto, 2007, Portela, et al., 2010), or the correct specification of human capital in the growth regression (in terms of a log specification in the context of a production function or in terms of levels as in a Mincerian specification, see, e.g., Krueger and Lindahl, 2001). To the best of our knowledge, however, no consensus has been reached regarding the effect of human capital on growth.

This paper suggests an explanation for the contradictory findings in the literature that complements earlier explanations, and that can rationalize these findings within a coherent framework by focusing attention on the specification of the empirical growth equation. This focus is motivated by the fact that the theoretical growth literature predicts human capital to affect growth through two distinct channels. On the one hand, human capital might accelerate growth by augmenting or complementing the existing factors of production as in an augmented Solow (1956) framework or in a model along the lines of Lucas (1988). On the other hand, human capital might affect growth through facilitating the diffusion and adoption of new technologies in the tradition of Nelson and Phelps (1966) or through innovation as in endogenous growth models in the tradition of Romer (1990) and Aghion and Howitt (1992), see also Hanushek and Woessmann (2008). If indeed both of the proposed channels are relevant for economic growth, estimates which are based on restrictive specifications that only account for a subset of these channels are likely to suffer from an omitted variable bias.

In an empirical growth application, the first channel is captured by the effect of changes in the stock of human capital on growth, while the second channel is reflected in the effect of the (initial) level of human capital on growth. If both channels are active and changes in human 
capital are correlated with initial levels, estimates that only account for one of the two effects are likely to be biased, since they omit a relevant measure of human capital that is correlated with the included but distinct measure of human capital. The issue of a bias arising in estimates that concentrate exclusively either on the Lucas approach to human capital, or on the Nelson-Phelps approach has been pointed out recently in the context of the effect of life expectancy on growth by Aghion et al. (2009). They focus on the effect of life expectancy, arguing that the omitted variable bias arising from the omission of the initial level of human capital in a growth regression is minor due to the weak evidence for convergence in human capital, as suggested by the findings of Morrison and Murtin (2009). This paper shows, however, that the argument indeed applies more generally to the debate on the growth effects of human capital when one considers the typical data sets and specifications applied in this literature.

The point is demonstrated by replicating some of the influential recent studies on the topic, using the respective different original data sets that have been used in the literature. In particular, our analysis uses the different human capital data sets provided by Cohen and Soto (2007), by Barro and Lee (2010), and by Lutz, Goujon, and Sanderson (2007), and replicates the typical specifications estimated in the literature, in particular those estimated in Cohen and Soto (2007), Krueger and Lindahl (2001), Benhabib and Spiegel (1994), and Mankiw et al. (1992). The results provide a picture that is consistent with the weak evidence obtained from previous studies which mostly focused on restrictive specifications that accounted either for the growth effects of initial human capital levels, or of the effect due to changes in human capital. Estimating an extended specification, however, we find consistently positive and significant effects of human capital in levels and in changes.

The explanation of weak empirical findings as consequence of a misspecification of the empirical growth model complements the alternative explanations for the inconclusive evidence on the growth effects of human capital that have been proposed in the literature. The present study sheds new light on the debate, however, by drawing attention to a specification issue that pervades the entire literature, which has been emphasizing different specification problems and the role of measurement error as a likely source of bias. The estimates replicate those of Cohen and Soto (2007) and show that the bias from neglecting a relevant human capital variable arises even when considering their improved human capital measures. A similar argument applies to using the updated data by Barro and Lee (2010) and the data compiled by Lutz et al. (2007), suggesting that measurement of data is certainly central for the quantitative effects, but that omitted variable bias due to a parsimonious specification of human capital in the growth re- 
gression is another important aspect for empirical estimates. Likewise, the results show that the bias arises regardless of whether human capital is measured in average years of schooling or in log years of schooling, complementing arguments by Krueger and Lindahl (2001). Finally, we document similar results when using input-based measures of human capital quality, rather than quantitative measures.

The paper is structured as follows. The next section presents our argument. Section 2 describes the data for the empirical application, section 3 presents results that replicate and rationalize earlier findings in the literature, and section 4 concludes with a brief discussion.

\section{Econometric Specification and the Growth Effect of Human Capital}

Consider the canonical empirical growth model, that combines the different channels of human capital on output growth. For illustrative purposes, this canonical model can be written as

$$
g_{i, t}=\ln y_{i, t}-\ln y_{i, t-1}=\alpha+\beta \ln h_{i, t-1}+\gamma \Delta \ln h_{i, t}+\Gamma X_{i, t-1}^{\prime}+\Lambda \Delta Z_{i, t}+\varepsilon_{i t},
$$

where $g_{i, t}$ is the growth rate of annual real per capita GDP, $y$, in country $i$ between periods (years) $t-1$ and $t$, and the vectors $X$ and $\Delta Z$ include other controls that have been considered in the empirical growth literature, either in levels as of $t-1$, such as lagged income to account for convergence effects, or in changes between $t-1$ and $t$, for instance in log physical capital, respectively. The corresponding coefficient vectors are captured by $\Gamma$ and $\Lambda$. The main interest lies on the effect(s) of human capital, reflected by $\beta$ and $\gamma$, where $\ln h_{i, t-1}$ is the initial level of the human capital measure, which is typically measured by the log of average school years (e.g., taken from the data assembled by Barro and Lee, 2001), and $\Delta \ln h_{i, t}$ is the change in log average school years. ${ }^{1}$ The effect of human capital in terms of an increase in effective factors as in an augmented Solow framework or along the lines of a Lucas model is reflected by the coefficient $\gamma$, while $\beta$ accounts for growth effects of human capital due to the higher adaptiveness to a changing environment in the spirit of Nelson and Phelps.

Estimating a growth model that only includes $\Delta \ln h_{i, t}$ but that disregards $\ln h_{i, t-1}$, as in

\footnotetext{
${ }^{1}$ To derive this empirical model, consider for example a growth-accounting model as in Benhabib and Spiegel (1994), in which aggregate income, $Y$ depends on physical capital $K$, labor $L$, productivity $A$ and human capital $H$, with $Y_{t}=A_{t} K_{t}^{\lambda} H_{t}^{\gamma} L_{t}^{\zeta}$. Combining this with a simplified version of productivity improvements over time that depend on the level of human capital, i.e., $\ln A_{t}-\ln A_{t-1}=\alpha_{0}+\beta \ln H_{t-1}$, one can derive an estimation equation as in (1).
} 
many earlier studies delivers a regression estimate of the growth effect of

$$
\hat{\gamma}=\gamma+\beta \cdot \frac{\operatorname{Cov}\left(\Delta \ln h_{i, t}, \ln h_{i, t-1}\right)}{\operatorname{Var}\left(\Delta h_{i, t}\right)} .
$$

Likewise, estimating a model that only contains $\ln h_{i, t-1}$, but not $\Delta \ln h_{i, t}$ delivers an estimate

$$
\hat{\beta}=\beta+\gamma \cdot \frac{\operatorname{Cov}\left(\ln h_{i, t-1}, \Delta \ln h_{i, t}\right)}{\operatorname{Var}\left(h_{i, t-1}\right)} .
$$

In both cases, the estimates are biased if growth is indeed affected by initial level and changes in human capital as predicted by theory (i.e., if $\beta>0$ and $\gamma>0$ ), and if the accumulation of human capital exhibits some sort of convergence or divergence process (i.e., if $\operatorname{Cov}\left(\Delta \ln h_{i, t}, \ln h_{i, t-1}\right) \neq$ $0)^{2}$ Whether this is the case is ultimately an empirical question that we investigate in the remainder of this study.

\section{Data}

Our analysis replicates earlier studies on the growth effects of human capital, using the data sets and sources as well as specifications that have been applied most frequently. We consider different data sources in order to document the consistency of our results with earlier findings and to demonstrate the relevance of the correct specification by accounting for the different growth channels of human capital. The estimations are based on the typical cross-country empirical growth model that has been estimated in the literature by using data for GDP, GDP per capita and investment from the Penn World Table (version 6.3), and population data from the UN. ${ }^{3}$ As a benchmark, we use the original data set constructed by Cohen and Soto (2007), which contains data for 81 countries over the period 1970-1990 and measures human capital in terms of the average years of schooling of the population aged $25+$ in each country. An alternative data source for measures of human capital in terms of average years of schooling of the population aged $25+$ is the most recent release of the data constructed by Barro and Lee (2010) for 97 countries. As a third data set for human capital, we use the data constructed by Lutz et al. (2007) (IIASA-VID data set), which we have for 88 countries over the period 1970-2000. ${ }^{4}$ Additional robustness checks investigate the relevance of the empirical specification

\footnotetext{
${ }^{2}$ This illustration implicitly assumes that (1) is correctly specified. Analogous biases apply to the estimates of the other coefficients in $\Gamma$ and $\Lambda$ if the respective regressors are correlated with the omitted variable.

${ }^{3}$ The data sources are http://pwt. econ.upenn.edu and http://esa.un.org/unpp/index . asp?panel=2.

${ }^{4}$ The original data by Cohen and Soto (2007) serves as a benchmark. For the alternative data sets, we construct measures of capital per worker using data from the Penn World Tables 6.3 using the method proposed by Caselli (2004), which is also used in Barro and Lee (2010).
} 
also for qualitative measures of human capital. ${ }^{5}$

The benchmark estimates are based on long differences over the period 1970-1990 and 19702000. The choice of this period maximizes the overlap between the data sets used in the literature and thus the comparability of our results with previous results in the literature. ${ }^{6}$ Since the samples differ with respect to their coverage of countries across data sets, this implies slightly different sample sizes and sample compositions across the different estimation samples. This serves as additional robustness check and generates variation that is helpful to identify the effect of human capital because as a consequence the data sets exhibit slightly different convergence processes in human capital. In particular, this helps to illustrate the importance of estimating fully specified models as in (1). The summary statistics of the main variables that are used for estimation in the three different samples over the observation period 1970-1990 are reported in Table 1.

\section{Empirical Results}

\subsection{Main Results}

In order to gauge the potential relevance of the bias that arises from only accounting for one of the two human capital channels, we begin by presenting the (unconditional) correlation between initial levels of human capital and the subsequent changes. Figure 1 plots the relationship between initial human capital (in terms of the log average years of schooling) in 1970, against the subsequent change in human capital (in terms of log average years of schooling) between 1970 and 1990, for the three different data sets. Figure 1(a) reveals a strong negative (unconditional) correlation between the log average years of schooling and the subsequent change in log years of schooling in the Cohen-Soto data, indicating that the (percentage) change in human capital is smaller the higher the initial log years of schooling. The negative correlation $(\rho=-0.84, \mathrm{p}$-value $<0.01)$ suggests that any estimate of the effect of human capital on growth that is based on a specification with only log changes or only log initial levels of human capital as regressor should be biased downward if both channels are indeed active as becomes clear from the expressions in

\footnotetext{
${ }^{5}$ We use the ratio of teachers per student on the primary and secondary schooling level as inputbased measure for the quality of human capital. The respective data sources are the Unesco (taken from http://www.uis.unesco.org/en/stats/statistics/indicators/indico.htm), as well as Altinok and Murseli (2007).

${ }^{6}$ The different data sets for human capital differ with respect to the time periods they cover. The data by Barro and Lee (2010) cover the period 1950-2010, the data by Cohen and Soto (2007) cover the period 1960-1990, and the data by Lutz et al. (2007) cover the period 1970-2000.
} 
(2) and (3).

Panel A of Table 2 presents the corresponding estimates for growth regressions, using the same data and specification as Cohen and Soto (2007). Column (1) presents the results for the effect of human capital, in terms of the change in log years of schooling, on growth in GDP per capita. The effect is insignificant and negative, similar to the findings reported by Benhabib and Spiegel (1994) that gave rise to the lengthy debate on the role of human capital in the first place. A specification with human capital in terms of log of initial years of schooling as in column (2) delivers a positive but small effect of human capital on growth, consistent with the findings of Mankiw et al. (1992). Column (3), finally, presents the results for a specification that accounts for both channels. The estimates reveal significant and positive effects of the change and of the initial level of human capital, with both coefficients being larger than their counterparts in columns (1) and (2), consistently with what one would expect from the correlation pattern and the biases in conditions (2) and (3). Both human capital measures are also jointly significant. ${ }^{7}$ This finding is in line with the conjecture that the presence of a strong convergence process in log years of schooling has important implications for the results obtained with a parsimonious specification and suggests that the weak empirical evidence on the growth effect of human capital might be the result of a sizable omitted variable bias due to the misspecification of human capital in the empirical model. ${ }^{8}$ An important possible caveat in this context is the potential multicollinearity problem that arises from a high correlation between initial human capital and change in human capital. However, moderate levels of variance inflation factors in the respective estimations (like column (3) of Table 2) suggest that multicollinearity is not a serious problem for the results. ${ }^{9}$

\footnotetext{
${ }^{7}$ The significance level of the respective F-statistic is given in the bottom line of the panel together with the number of observations.

${ }^{8}$ Extensive specification tests deliver no indication of misspecification for the estimates with both human capital variables, based on tests of normality of the residuals (which cannot be rejected), heteroskedasticity (for which there is no indication after estimating robust standard errors), or additional omitted variables (for which we have no indication based on overidentification tests using nonlinear transformations of residuals or regressors).

${ }^{9}$ The corresponding variance inflation factors (VIF) for specification (3) are 3.79 for the log change and 6.29 for the initial log level of schooling, which is substantially below the level of 10 that is considered to be critical in the econometrics literature, see, e.g., Kennedy (2008, p.199). An alternative way to investigate the hypothesis while circumventing possible multicollinearity is to conduct a principal component analysis of $\Delta \ln h$ and $\ln h$. This delivers two alternative variables as linear combinations of the two original human capital variables. While these alternative variables still contain most of the variation of the human capital variables and are comparable since both human capital variables are measured in the same units, they are uncorrelated by construction. Repeating the estimates with these two orthogonal components as regressors instead of $\Delta \ln h$ and $\ln h$ in the specification (1) should deliver similar results in the present context, in the sense that theory would still predict a positive coefficient
} 
We continue by investigating whether our explanation based on misspecification of human capital in the growth equation can account for findings that have been reported for different data sets and across different time periods. Figure 1(b) depicts a scatter plot for the convergence in $\log$ years of schooling for the same period 1970-1990, but using data from Barro and Lee (2010) instead. Again, we find a negative correlation when considering logged schooling variables $(\rho=-0.83, \mathrm{p}$-value $<0.01)$. The corresponding results of growth regressions are presented in columns (4), (5), and (6) of Table 2. The results are qualitatively identical to those obtained with the Cohen-Soto data. Again, the point estimate of the log difference in schooling is negative when estimated in isolation (column 4), the effect of the initial value of the log-transformed years of schooling is positive but small (column 5). These results prevail despite the further improved data quality compared to the data provided by Cohen and Soto (2007). Most importantly, however, the inconclusive evidence disappears also in the sample of 97 countries, once both channels of human capital are accounted for. As shown in column (6), the coefficients of both human capital variables become larger and significant when estimated in a joint specification. This finding is again consistent with the explanation of a bias due to omitting a relevant human capital variable that affects the results in columns (4) and (5). ${ }^{10}$

Finally, Figure 1(c) displays the convergence pattern in human capital over the period 19701990 using the IIASA-VID data set constructed by Lutz et al. (2007). As before, logged years of schooling exhibit a substantial correlation $(\rho=-0.93$, p-value $<0.01)$. Accordingly, one would expect a downward bias in the specifications with only one human capital variable. This hypothesis is confirmed in the estimation results, see columns (7), (8) and (9) of Table 2. Again, we find significant positive effects of human capital, in terms of initial levels and changes in years of schooling, in the full specification. ${ }^{11}$ The coefficient estimates are larger in the joint specification than what is obtained when including only one human capital variable, in line with the expected omitted variable bias affecting the parsimonious specifications. A remarkable of both variables if both human capital channels are active. This in fact turns out to be the case. Estimates using the two principal components as regressors reveal positive effects on growth of both components, which are individually and jointly significant. This is in line with the results obtained with the raw human capital measures and suggests that the previous results are not likely to be affected by serious problems of multicollinearity, but rather, that human capital indeed affects growth through both distinct channels.

${ }^{10}$ The corresponding variance inflation factors are even smaller in this case $(3.43$ for $\hat{\gamma}$ and 5.71 for $\hat{\beta})$.

${ }^{11}$ With variance inflation factors lower than 10 for the extended logged human capital specification (7.60 for $\hat{\gamma}$ and 9.95 for $\hat{\beta}$ ), multicollinearity does not seem to greatly affect the results also in this data set. A principal component analysis analogous to the one discussed in footnote 9 also delivers individual and joint significance of both factors. 
difference with regard to the previous findings is the consistently larger effects of human capital, in terms of $\beta$ and $\gamma$ in the VID-IIASA data. This might be related to the different methods used in the construction of the data and shows the robustness of the results in data sets which are more immune to the criticism of Portela, et al. (2010). ${ }^{12}$ Finally, it is worth mentioning that in the IIASA-VID data the coefficient on the change in physical capital is more in line with the typical estimates of the capital-income share than in the previous results from other data sets. The more general point in this context is that even when conditioning on the inclusion of physical capital (that earlier contributions like Krueger and Lindahl, 2001, suspected to drive the weak human capital results), the full specification delivers estimates of a significant positive effect of human capital on growth, regardless of the data set we use.

\subsection{Levels of Schooling and Macro-Mincer Specifications}

This subsection shows that the conclusion from the previous findings that human capital is likely to affect growth through both channels, initial levels and changes, is unchanged when considering different specifications of human capital. In particular, several authors, including Topel (1999) and Krueger and Lindahl (2001) have criticized the specification of human capital in terms of logged variables as a potential source of bias and misspecification. ${ }^{13}$ These authors suggest that the growth equation should be specified by explicitly accounting for the log-linear relationship between earnings and education that emerges from a Mincerian human capital production function. In other words, rather than specifying the growth equation as in (1), these studies recommend a specification in levels of human capital,

$$
g_{i, t}=\ln y_{i, t}-\ln y_{i, t-1}=\alpha+\beta h_{i, t-1}+\gamma \Delta h_{i, t}+\Gamma X_{i, t-1}^{\prime}+\Lambda \Delta Z_{i, t}+\varepsilon_{i t},
$$

where $h_{i, t-1}$ and $\Delta h_{i, t}$ are levels and changes in human capital (e.g., in terms of average years of schooling), instead of the respective variables in logs as in (1).

In terms of the correlation between lagged levels and subsequent changes in average years of schooling, the picture looks slightly different than when considering the respective logged variables. Figure 2(a) shows that there is a weak positive relation between initial level and

\footnotetext{
${ }^{12}$ Rather than using enrolment data and applying the perpetual inventory method as in the data constructed by Cohen and Soto (2007) and Barro and Lee (2010), Lutz et al. (2007) use data on actual education attainments and apply back-projection methods that take into account age-specific mortality, and thus provide a complementary measure of human capital by construction.

${ }^{13}$ Topel (1999) notes that using logged variables imply that an additional year of schooling increases the stock of human capital by a larger proportional amount in countries with little education than in countries with more education, which he argues is inconsistent with the evidence on the human capital production function.
} 
subsequent change in average years of schooling in the data from Cohen and Soto $(\rho=0.28$, p-value $<0.05)$. This positive relationship implies that estimates obtained with a specification that only includes changes or initial levels of years of schooling (in terms of $\hat{\gamma}$ or $\hat{\beta}$ ) should only exhibit a weak bias, which, if anything, should be upward (rather than downward, as was the case when considering logs).

Estimation results are presented in Table 3, where we repeat the same analysis as in Table 2 , but apply a macro-Mincer approach instead of a production function approach. The human capital variables in this specification are lagged years of schooling and the change in years of schooling. The results in columns (1), (2) and (3) are based on the data constructed by Cohen and Soto (2007). In line with the findings reported by Krueger and Lindahl (2001), we find a positive significant effect of the change in schooling (column 1) and the lagged years of schooling (column 2) in isolation. The joint specification (3) delivers positive and significant effects of human capital through both channels as well, but now the point estimates are slightly smaller than the corresponding ones in columns (1) and (2). This finding is consistent with the implications of a small bias from neglecting a relevant human capital variable, which one would expect due to the weakly positive correlation in lagged levels and changes, as shown in Figure 2(a). ${ }^{14}$ But while estimates obtained with a reduced Macro-Mincer specification with only one human capital variable exhibit only a small bias, the results suggest that reduced specifications nevertheless are misspecified, given the individual and joint significance of both human capital measures in the full specification in column (3).

Figure 2(b) displays the convergence pattern for the data constructed by Barro and Lee (2010). The correlation between initial levels and changes in human capital in terms of average years of schooling is positive but rather weak $(\rho=0.09$, p-value $<0.40)$. Columns $(4),(5)$ and (6) of Table 3 present the corresponding estimation results. The specification in levels delivers a positive effect in all specifications, and the differences in the coefficient estimates between the reduced specifications and the full specification in column (6) are minor, which is to be expected given that the correlation between lagged levels and changes in years of schooling is weak in this data set. Notably, the size of the estimated coefficients is very similar across the samples of data by Cohen and Soto (2007) and Barro and Lee (2010). Finally, Figure 2(c) presents the convergence in human capital for the VID-IIASA data prepared by Lutz et al. (2007). The correlation in human capital is weakly negative in this data set ( $\rho=-0.12$, p-value

\footnotetext{
${ }^{14}$ Similar specification tests as before indicate that the model specification in column (3) is appropriate. In particular, the moderate correlation between the human capital variables does not appear to raise issues of multicollinearity.
} 
$<0.29$ ), as was the case for the logged variables in the previous section. The corresponding estimation results in columns (7), (8) and (9) of Table 3 again suggest that the effect of human capital on growth is positive when considering changes in years of schooling (column 7), but not significant in the specification with lagged levels of human capital (column 8). The joint specification in column (9) delivers positive and significant effects of human capital through both channels with coefficient estimates that are larger than when estimated in isolation. Overall the main point that human capital affects growth through two distinct channels is unaffected by whether one considers a growth-accounting framework with human capital variables in logs, or a Macro-Mincer specification with human capital in levels.

\subsection{Robustness}

The conclusion that human capital affects growth through both channels, through the change and the initial level, is supported also in alternative estimation frameworks. In this section, we present results for alternative sample periods, for alternative specifications of the growth equation, for samples that correct for outlier observations, as well as for measures of human capital quality.

Alternative Sample Periods. The data sets by Barro and Lee (2010) and IIASA-VID (2007) cover the years 1970-2000, which allows us to test the robustness of the previous findings for estimates over an extended time window. Figure 3 presents the respective scatter plots for the (unconditional) correlation between (log) years of schooling in 1970 and the change in (log) years of schooling over the period 1970-2000. As before, we find strong indications of convergence (in terms of a negative relation) for log average years of schooling, and a weaker convergence pattern for years of schooling in absolute terms. In both data sets, there is a negative correlation between changes in human capital and initial levels, measured either in years of schooling or logs. ${ }^{15}$

Table 4 presents the respective estimation results over the longer period 1970-2000 for the data sets by Barro and Lee (2010) as well as Lutz et al. (2007). The results are comparable to the corresponding results in Tables 2 and 3. The growth effect of human capital in the full specification appears even stronger over the longer time horizon, and the point estimates are typically larger in the full specification than in the specifications with only one human capital variable, again consistent with the direction of the bias that can be expected given the

\footnotetext{
${ }^{15}$ In the Barro-Lee data, the correlations are $\rho=-0.87(\mathrm{p}$-value $<0.01)$ and $\rho=-0.04(\mathrm{p}$-value $<0.71)$ for logged years of schooling and years of schooling, respectively. In the IIASA-VID data, the corresponding correlations are $\rho=-0.96$ (p-value $<0.01)$ and $\rho=-0.20(\mathrm{p}$-value $<0.07)$.
} 
correlation between lagged levels and changes of human capital. ${ }^{16}$ This finding is consistent with the arguments by Krueger and Lindahl (2001) and Portela et al. (2010) that the use of longer time horizons for the estimates of growth effects of human capital might deliver more robust estimates due to the higher signal to noise ratio.

Using the data by Barro and Lee (2010), it is also possible to estimate models in long differences over the 40-year horizon, from 1965-2005. The corresponding results for the benchmark specification are presented in Panel (A) Table 5. In line with the previous results, we find overall larger coefficients for the 40-year horizon. Most importantly, however, the use of a longer time period leaves the main results unaffected. On the contrary, the negative effect of the change in log average years of schooling in column (1) is even larger and significant. Most importantly, the joint specifications (3) and (6) consistently deliver positive and significant growth effects of human capital through both channels. With two adjacent 20-year periods, it also becomes possible to use lagged human capital variables to ensure that human capital is predetermined. The corresponding results in Panel (B) of Table 5 deliver smaller coefficient estimates. Nevertheless, qualitatively the picture remains unaffected, and both human capital variables remain jointly significant in the full specification, both in column (3) and (6).

Alternative Specifications. Table 6 presents corresponding results for a growth regression with growth in aggregate GDP as dependent variable on a specification that controls for growth in the population aged $25+$. This specification complements the previous specifications with growth in GDP per capita as dependent variable and resembles a prominent specification in the empirical growth accounting literature, see, e.g., the specifications used by Benhabib and Spiegel (1994). In general, the qualitative findings are similar to our baseline results. In particular, we typically obtain positive growth effects of human capital that are, at least jointly, significant. The only exception are the results in Panel A obtained with the data set of Cohen and Soto (2007), where the human capital effects are positive but not significant individually or jointly. A possible explanation for this finding is that normality of the residuals for both specifications is rejected based on Shapiro-Wilk tests $(p<0.05)$ for the estimates with this data set, suggesting the

\footnotetext{
${ }^{16}$ The data by Cohen and Soto only cover the sample period 1960-1990, but for comparability with the data constructed by Lutz et al. (2007), which only start in 1970, we chose 1970-1990 as the benchmark period of observation. Replicating the results with the Cohen and Soto (2007) data for the sample period 1960-1990 for 64 countries leads to very similar results, with estimates [standard errors] of $\hat{\gamma}=0.416^{* *}[0.172]$ and $\hat{\beta}=0.013^{* * *}$ [0.004] for the specification with logged human capital variables, and $\hat{\gamma}=0.093^{* * *}[0.029]$ and $\hat{\beta}=0.0014^{* *}$ [0.0006] for the specification with human capital variables in years, respectively. Detailed results are available upon request.
} 
relevance of influential observations. Once we eliminate outliers by eliminating the observations with $10 \%$ largest residuals in absolute terms, respectively, we obtain coefficient estimates for the specifications (3) and (6) that are individually (and jointly) highly significant $(p<0.01) .{ }^{17}$ In general, it appears as if specifications that explicitly control for population growth are more prone to outlier observations, which reinforces the point of Temple (1999). Over the extended sample period 1970-2000, we find again consistently positive and significant effects of human capital on growth in the full specification, see Table 7.

Similar results apply when estimating an extended specification along the lines of Mankiw et al. (1992). Table 8 presents results that replicate their Table II results for income levels (Panel A), and their Table $\mathrm{V}$ for growth allowing for convergence effects (Panel B) for their sample that excludes oil countries. ${ }^{18}$ When considering the income specification (Panel A), we find a strongly negative effect of changes in log human capital (specification (1)), while the specification with only initial log human capital delivers a highly significant positive effect (specification (2). ${ }^{19}$ Once lagged human capital and changes in human capital are jointly incorporated in specification (3), we obtain a positive and significant effect for each (log) human capital measure, in line with the implication of a downward bias resulting from the strong negative correlation between lagged human capital and changes in human capital displayed in Figure 1(b). In the Mincerian framework with human capital in years of schooling, we find significant effects of both lagged human capital and changes in human capital in isolation as well as in the joint specification. The importance of considering the possibility of both channels of human capital effects is illustrated when turning to the respective growth regressions in Panel B. For logged human capital measures in isolation in specifications (1) and (2), we find no effect at all. Once both channels are accounted for in specification (3), however, the effect of lagged human capital and of changes in human capital is significant and positive individually and jointly. ${ }^{20}$

Outliers. Given the small samples and the differences in data quality across countries, some scholars have been concerned about the role of outliers for estimates of the growth effects of human capital. In order to investigate whether and to what extent the previous results are

\footnotetext{
${ }^{17}$ Shapiro-Wilk tests in this sample cannot reject the null of normality of residuals in these regressions.

${ }^{18}$ Effectively, their specification is extended by adding the change in human capital, which can be rationalized by the fact that their specification accounts for population growth, but not for growth in the stock of human capital.

${ }^{19}$ Mankiw et al. include average human capital over their sample period as explanatory variable, while we use the level at the beginning of the sample period, instead. The human capital data are taken from Barro and Lee (2010).

${ }^{20}$ The respective p-values of tests of joint significance are below 0.06 .
} 
affected by outliers, we repeat the estimations of Table 2 by eliminating the observations with the largest absolute residuals. In particular, we re-estimate the growth equations on a sample from which the $5 \%$ of observations with the highest and the $5 \%$ with the lowest residuals (based on the full specification including both human capital measures in years or logs) have been eliminated. The results are presented in Table 9. The coefficient estimates are very similar to the estimates reported on the full samples in Table $2 .{ }^{21}$ In particular, we find the same patterns of omitted variable bias in the parsimonious specifications that only include one measure of human capital. The fact that the estimates in the full specification are slightly larger when using the trimmed sample suggest that outliers might indeed weaken the results, but the results overall suggest that outliers do not drive the main findings with respect to the correct specification of the growth effects of human capital. When applying robust regression techniques to account for the influence of outliers, rather than manual trimming, we find qualitatively and quantitatively similar results to the baseline estimates. ${ }^{22}$

Quality of Human Capital An issue that has received considerable attention in the literature as potential reason for the weak effects of human capital on growth is the focus on quantitative measures such as average years of schooling. Several authors have suggested to account for the quality of human capital in terms of the existing stock of knowledge in the population by using measures based on teaching inputs or output measures like test scores. ${ }^{23}$ The use of test-scores as an output-based measure of human capital quality is impracticable for the purposes of this paper since since test score-based measures are not available for most countries as early as 1960 or 1970. To investigate the consequences of applying measures of human capital quality rather than years of schooling, we have therefore conducted the same analysis using the teacher/student ratio as input based measure for the quality of human capital. ${ }^{24}$ This measure

\footnotetext{
${ }^{21}$ For the data of Cohen and Soto (2007), this implies trimming the data set by eliminating the 4 countries with the lowest residuals and the 4 countries with the highest residuals. For the Barro and Lee (2010) data, we eliminate 5 countries at each extreme of the distribution of residuals. The Lutz et al. (2007) data are also trimmed by eliminating $10 \%$ of the countries as outliers ( 5 at the top of the distribution of residuals, 4 at the bottom in the $\log$ specifications, and 4 at the top and 5 at the bottom in the level specification). Note that the similarity of coefficient estimates to the estimates obtained with the full samples is another indication that multicollinearity does not affect the main results.

${ }^{22}$ Details are available upon request.

${ }^{23}$ For a detailed discussion of the pros and cons of input-based measures of human capital quality see Hanushek and Woessmann (2008).

${ }^{24}$ We used data on input-based measures of human capital in terms of the teacher/student ratio for primary and secondary schools from two different sources, the Unesco and the data set constructed by Altinok and Murseli (2007), which is larger but potentially less comparable across countries in terms of how the data were constructed.
} 
has been used repeatedly in the literature to investigate student quality and its determinants, see, e.g., Card and Krueger (1992), but overall the results have been mixed as to whether the teacher/student ratio or related measures of expenditures on education have an impact on the quality of human capital and growth, see Hanushek (2002) for a critical review. In summary, however, we obtain a qualitatively similar picture to the previous results when using measures of human capital quality. In particular, the estimates suggest that the general pattern, namely that human capital exerts a positive and (at least jointly) significant effect on growth through both channels, changes and initial levels of human capital, prevails also when using measures of human capital quality rather than years of schooling. ${ }^{25}$

\section{Discussion}

The existing evidence on the growth effects of human capital in the literature is weak and inconclusive, which has raised an intense debate that has not been fully reconciled. The findings of this paper suggest that misspecification of human capital in the empirical growth model can provide an alternative explanation for the inconclusive evidence in the literature. The misspecification arises if human capital affects growth through the two distinct channels identified in the previous literature, changes in human capital and initial levels in human capital. When human capital is measured in log average years of schooling, both measures, changes and initial levels, are highly correlated in the data, which implies that estimates obtained with models that only include one channel are likely to be seriously biased. This bias is much smaller when human capital measures are included in levels, as in the Macro-Mincer approach that has been applied frequently in the recent literature, due to the weaker correlation in these measures of human capital. Indeed, there is a crucial difference between specifying human capital in levels or logs in light of the different implications for the emerging bias, because of the different convergence patterns in the human capital variables, as has been shown in Figures 1 and 2. Nevertheless, our results indicate that even in Macro-Mincer specifications human capital consistently affects growth through both channels. This implies that estimates obtained with specifications that only include one channel do not deliver an estimate of the overall relevance of human capital for growth because they omit a relevant channel.

The present study therefore complements the existing literature by highlighting the crucial role of the correct specification of human capital in growth regressions, regardless whether human capital is measured in levels or logs. This distinction (levels or logs) has been proposed earlier

\footnotetext{
${ }^{25}$ Detailed results are available upon request.
} 
as an explanation, e.g., by Krueger and Lindahl (2001) for the weak growth effects. This study also relates to arguments pointing at the role of data quality and the content of human capital variables (in terms of quantity versus quality of schooling). The current results strongly indicate that, apart from the emphasis of the role of data quality in recent studies (as in de la Fuente and Domenech, 2006, Cohen and Soto, 2007, or Portela et al. 2010), or from conditioning on other variables like physical capital (as in Krueger and Lindahl, 2001), the correct specification of the human capital component plays a more important role than suggested by these contributions. In fact, these studies mainly report significant positive effects of human capital in specifications according to the Mincerian approach, in particular when they include both levels and changes in human capital. The systematic investigation of the relevance of the specification in this study reinforces the importance of the literature on measurement issues, however, since accurate measures of human capital are indispensable for reliable quantitative estimates of the growth effects of human capital, in addition to the correct specification. Finally, by documenting a strong and robust growth effect of human capital in a comprehensive specification of the empirical growth model, our results provide important information for studies that try to delve deeper into identifying a causal role of human capital for growth. 


\section{References}

Aghion, P., And P. Howitt (1992): "A Model of Growth Through Creative Destruction," Econometrica, 60(2), 323-351.

Aghion, P., P. Howitt, And Murtin (2009): "The Relationship Between Health and Growth: When Lucas Meets Nelson-Phelps," mimeo, Harvard University.

Altinok, N., and H. Murseli (2007): "International Database on Human Capital Quality," Economics Letters, 96(2), 237-244.

Barro, R. J. (2001): "Human Capital and Growth," American Economic Review, 91(2), 12-17.

Barro, R. J., And J.-W. Lee (2001): "International Data on Educational Attainment: Updates and Implications," Oxford Economic Papers, 53(3), 541-563.

(2010): “A New Data Set of Education Attainment in the World, 1950-2010," NBER Working Papers, 15902.

Benhabib, J., And M. Spiegel (1994): "The role of human capital in economic development: Evidence from aggregate cross-country data," Journal of Monetary Economics, 34(1), 143173.

Card, D., and A. B. Krueger (1992): "Does School Quality Matter? returns to Education and the Characteristics of Public Schools in the United States," Journal of Political Economy, 100(1), 1-40.

Caselli, F. (2004): "Accounting for Cross-Country Income Differences," NBER Working Paper, 10828.

Cohen, D., And M. Soto (2007): "Growth and Human Capital: Good Data, Good Results," Journal of Economic Growth, 12(1), 51-76.

De la Fuente, A., and R. Domenech (2006): "Human Capital in Growth Regressions: How Much Difference Does Data Quality Make?," Journal of the European Economic Association, $4(1), 1-36$.

Hanushek, E. A. (2002): "Public Provided Education," in Handbook of Labor Economics, ed. by A. Auerbach, and M. Feldstein, vol. 4, chap. 30, pp. 2045-2141. Elsevier Science B.V., Amsterdam.

Hanushek, E. A., and L. Woessmann (2008): "The Role of Cognitive Skills in Economic Development," Journal of Economic Literature, 46(3), 607-668.

Kennedy, P. E. (2008): A Guide to Econometrics. Blackwell, Oxford.

Krueger, A. B., And Lindahl (2001): "Education for Growth: Why and for Whom?," Journal of Economic Literature, 39(4), 1101-1136.

LuCAs, R. E. (1988): "On the Mechanics of Economic Development," Journal of Monetary Economics, 22(1), 3-42.

Lutz, W., A. Goujon, and W. Sanderson (2007): "Reconstruction of population by age, sex, and level of education attainment of 120 countries for 1970-2000," in Vienna Yearbook of Population Research, pp. 193-235. IAASA, Vienna. 
Mankiw, N., D. Romer, And D. Weil (1992): "A Contribution to the Empirics of Economic Growth," Quarterly Journal of Economics, 107, 407-437.

Morrison, C., And F. Murtin (2009): "The Century of Education," Journal of Human Capital, 3(1), 1-42.

Nelson, R., And E. Phelps (1966): "Investment in Humans, Technological Diffusion, and Economic Growth," American Economic Review, 51(2), 69-75.

Portela, M., R. Alessie, and C. Teulings (2010): "Measurement Error in Education and Growth Regressions," Scandinavian Journal of Economics, 112(3), 618-639.

Romer, P. M. (1990): "Endogenous Technological Change," Journal of Political Economy, 98(5), S71-S102.

Solow, R. (1956): "A Contribution to the Theory of Economic Growth," Quarterly Journal of Economics, 70(1), 65-94.

Temple, J. (1999): “A Positive Effect of Human Capital on Growth," Economics Letters, 65(1), $131-134$.

Topel, R. (1999): "Labor Markets and Economic Growth," in Handbook of Labor Economics, ed. by O. Ashenfelter, and D. Card, vol. 3b, pp. 2943-2984. Elsevier Science B.V., Amsterdam. 
Table 1: Summary Statistics: Baseline Sample Period (1970-1990)

\begin{tabular}{|c|c|c|c|c|c|c|c|c|c|}
\hline \multirow[t]{2}{*}{ Sample: } & \multicolumn{3}{|c|}{ Cohen and Soto (2007) } & \multicolumn{3}{|c|}{ "Barro and Lee (2010) } & \multicolumn{3}{|c|}{ IIASA-VID (2007) } \\
\hline & Mean & Std. Dev. & $\mathrm{N}$ & Mean & Std. Dev. & $\mathrm{N}$ & Mean & Std. Dev. & $\mathrm{N}$ \\
\hline$\Delta \ln \mathrm{Y}$ & 0.034 & 0.019 & 81 & 0.037 & 0.02 & 97 & 0.035 & 0.018 & 88 \\
\hline Lag $\ln \mathrm{Y}$ & 17.43 & 1.77 & 81 & 17.127 & 1.835 & 97 & 17.309 & 1.776 & 88 \\
\hline$\Delta \ln y$ & 0.011 & 0.02 & 81 & 0.017 & 0.021 & 97 & 0.015 & 0.02 & 88 \\
\hline Lag $\ln y$ & 8.750 & 0.972 & 81 & 8.293 & 1.006 & 97 & 8.231 & 1.014 & 88 \\
\hline$\Delta \ln \mathrm{h}$ & 0.026 & 0.017 & 81 & 0.03 & 0.021 & 97 & 0.032 & 0.022 & 88 \\
\hline Lag $\ln h$ & 1.041 & 1.025 & 81 & 0.964 & 0.943 & 97 & 0.927 & 1.096 & 88 \\
\hline$\Delta \mathrm{h}$ & 0.089 & 0.04 & 81 & 0.099 & 0.041 & 97 & 0.098 & 0.044 & 88 \\
\hline Lag h & 4.093 & 2.936 & 81 & 3.72 & 2.711 & 97 & 3.876 & 3.075 & 88 \\
\hline$\Delta \ln \mathrm{k}$ & 0.023 & 0.026 & 81 & 0.04 & 0.028 & 97 & 0.038 & 0.029 & 88 \\
\hline$\Delta \ln n$ & 0.023 & 0.009 & 81 & 0.024 & 0.009 & 96 & 0.023 & 0.009 & 88 \\
\hline
\end{tabular}




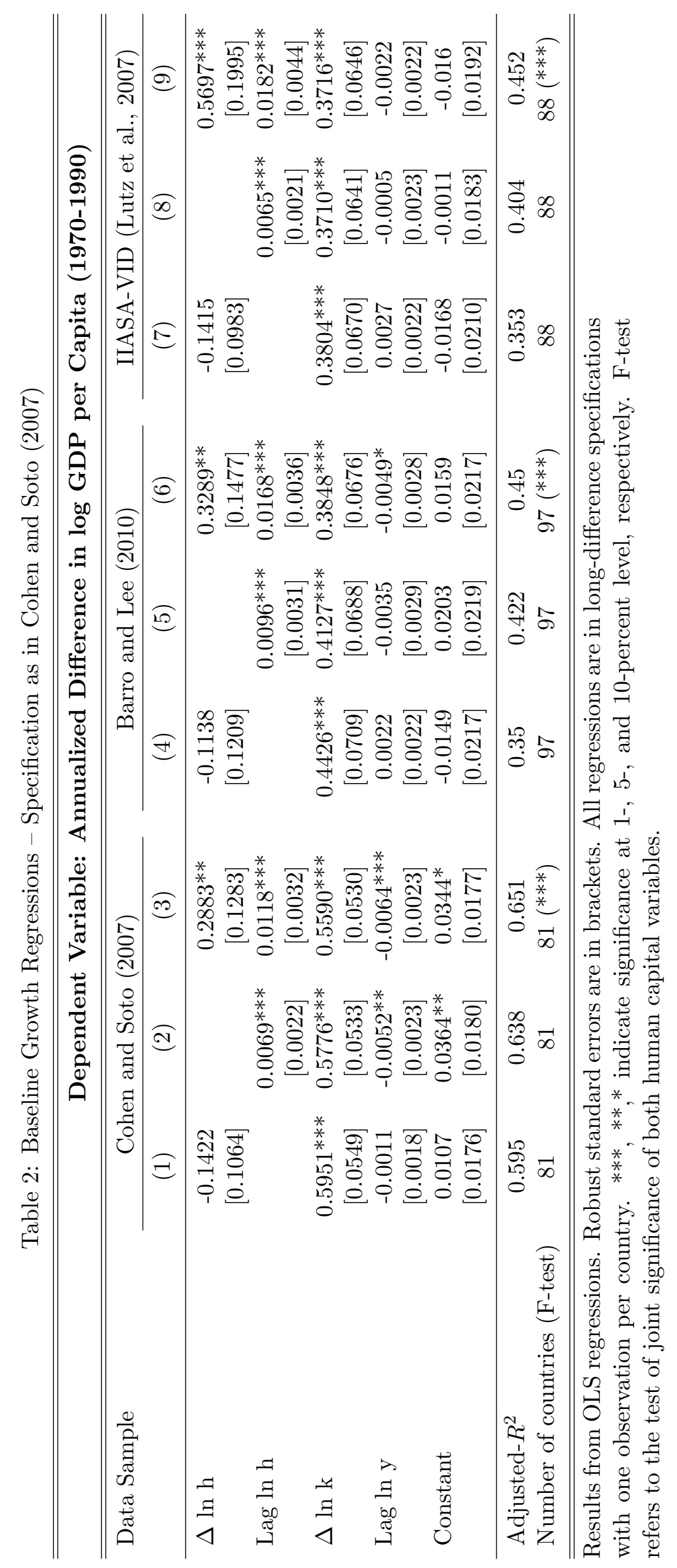




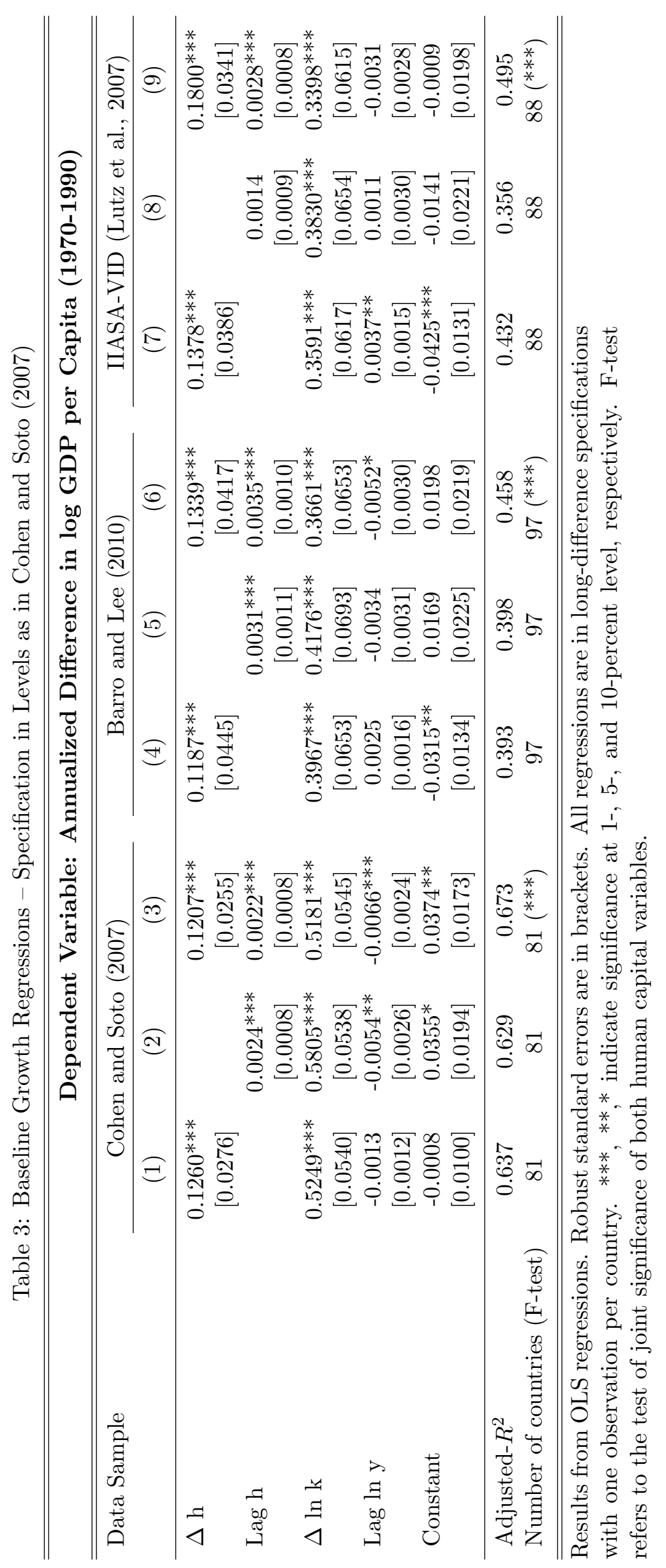


Table 4: Robustness - Baseline Specification as in Cohen and Soto (2007) Extended Sample Period 1970-2000

\begin{tabular}{|c|c|c|c|c|c|c|}
\hline & \multicolumn{6}{|c|}{ Dependent Variable: Annualized Difference in log GDP per Capita (1970-2000) } \\
\hline & \multicolumn{6}{|c|}{ Panel (A): Data from Barro and Lee (2010) } \\
\hline & \multicolumn{3}{|c|}{ Log-Specification } & \multicolumn{3}{|c|}{ Level-Specification } \\
\hline & $(1)$ & $(2)$ & $(3)$ & $(4)$ & $(5)$ & $(6)$ \\
\hline$\Delta \ln \mathrm{h}$ & $\begin{array}{l}-0.1554 \\
{[0.1189]}\end{array}$ & & $\begin{array}{c}0.4226^{* * *} \\
{[0.1551]}\end{array}$ & & & \\
\hline Lag $\ln \mathrm{h}$ & & $\begin{array}{c}0.0088^{* * *} * \\
{[0.0025]}\end{array}$ & $\begin{array}{c}0.0165^{* * *} * \\
{[0.0033]}\end{array}$ & & & \\
\hline$\Delta \mathrm{h}$ & & & & $\begin{array}{c}0.0887 * * \\
{[0.0356]}\end{array}$ & & $\begin{array}{c}0.1269 * * * \\
{[0.0318]}\end{array}$ \\
\hline Lag h & & & & & $\begin{array}{c}0.0027^{* * *} \\
{[0.0008]}\end{array}$ & $\begin{array}{c}0.0036 * * * \\
{[0.0008]}\end{array}$ \\
\hline$\Delta \ln \mathrm{k}$ & $\begin{array}{c}0.5174 * * * \\
{[0.0732]}\end{array}$ & $\begin{array}{l}0.4725^{* * *} \\
{[0.0686]}\end{array}$ & $\begin{array}{c}0.4468^{* * *} \\
{[0.0681]}\end{array}$ & $\begin{array}{c}0.4930 * * * \\
{[0.0676]}\end{array}$ & $\begin{array}{l}0.4838^{* * *} \\
{[0.0708]}\end{array}$ & $\begin{array}{c}0.4262^{* * *} \\
{[0.0663]}\end{array}$ \\
\hline Lag $\ln y$ & $\begin{array}{c}0.0019 \\
{[0.0019]}\end{array}$ & $\begin{array}{l}-0.0029 \\
{[0.0023]}\end{array}$ & $\begin{array}{l}-0.0041^{* *} \\
{[0.0021]}\end{array}$ & $\begin{array}{l}0.0031^{* *} \\
{[0.0013]}\end{array}$ & $\begin{array}{l}-0.0025 \\
{[0.0023]}\end{array}$ & $\begin{array}{l}-0.0050^{* *} \\
{[0.0022]}\end{array}$ \\
\hline Constant & $\begin{array}{l}-0.0112 \\
{[0.0187]}\end{array}$ & $\begin{array}{c}0.0174 \\
{[0.0172]}\end{array}$ & $\begin{array}{c}0.0099 \\
{[0.0169]}\end{array}$ & $\begin{array}{c}-0.0331^{* * *} \\
{[0.0116]}\end{array}$ & $\begin{array}{c}0.0125 \\
{[0.0169]}\end{array}$ & $\begin{array}{c}0.0188 \\
{[0.0161]}\end{array}$ \\
\hline Adjusted- $R^{2}$ & 0.484 & 0.553 & 0.584 & 0.506 & 0.524 & 0.587 \\
\hline \multirow[t]{4}{*}{ Number of countries (F-test) } & 97 & 97 & $97(* * *)$ & 97 & 97 & $97(* * *)$ \\
\hline & \multicolumn{6}{|c|}{ Panel (B): Data from IIASA-VID (Lutz et al., 2007) } \\
\hline & \multicolumn{3}{|c|}{ Log-Specification } & \multicolumn{3}{|c|}{ Level-Specification } \\
\hline & $(1)$ & $(2)$ & $(3)$ & $(4)$ & $(5)$ & $(6)$ \\
\hline$\Delta \ln \mathrm{h}$ & $\begin{array}{c}-0.1915^{* *} \\
{[0.0842]}\end{array}$ & & $\begin{array}{c}0.5249^{* *} \\
{[0.2271]}\end{array}$ & & & \\
\hline Lag $\ln \mathrm{h}$ & & $\begin{array}{c}0.0053^{* * *} \\
{[0.0015]}\end{array}$ & $\begin{array}{c}0.0148^{* * * *} \\
{[0.0043]}\end{array}$ & & & \\
\hline$\Delta \mathrm{h}$ & & & & $\begin{array}{c}0.0838^{* *} \\
{[0.0321]}\end{array}$ & & $\begin{array}{c}0.1373^{* * *} * \\
{[0.0294]}\end{array}$ \\
\hline Lag h & & & & & $\begin{array}{l}0.0013^{*} \\
{[0.0007]}\end{array}$ & $\begin{array}{c}0.0025 * * * \\
{[0.0006]}\end{array}$ \\
\hline$\Delta \ln \mathrm{k}$ & $\begin{array}{c}0.4719 * * * \\
{[0.0732]}\end{array}$ & $\begin{array}{c}0.4589 * * * \\
{[0.0697]}\end{array}$ & $\begin{array}{c}0.4515^{* * *} \\
{[0.0674]}\end{array}$ & $\begin{array}{c}0.4627 * * * \\
{[0.0698]}\end{array}$ & $\begin{array}{c}0.4781 * * * \\
{[0.0721]}\end{array}$ & $\begin{array}{c}0.4235^{* * *} \\
{[0.0651]}\end{array}$ \\
\hline Lag $\ln y$ & 0.0013 & $\begin{array}{l}-0.0005 \\
{[0.0018\rceil}\end{array}$ & $\begin{array}{l}-0.0018 \\
{[0.0018]}\end{array}$ & $\begin{array}{c}0.0032^{* *} \\
{[0.0013]}\end{array}$ & $\begin{array}{l}0.0005 \\
{[0.0022]}\end{array}$ & $\begin{array}{l}-0.0028 \\
{[0.0021]}\end{array}$ \\
\hline Constant & $\begin{array}{l}-0.0036 \\
{[0.0159]}\end{array}$ & $\begin{array}{c}0.0013 \\
{[0.0138]}\end{array}$ & $\begin{array}{l}-0.0114 \\
{[0.0149]}\end{array}$ & $\begin{array}{c}-0.0326^{* * *} \\
{[0.0112]}\end{array}$ & $\begin{array}{l}-0.0072 \\
{[0.0162]}\end{array}$ & $\begin{array}{c}0.0028] \\
0.0028 \\
{[0.0147]}\end{array}$ \\
\hline Adjusted- $R^{2}$ & 0.515 & 0.544 & 0.563 & 0.525 & 0.508 & 0.585 \\
\hline Number of countries (F-test) & 88 & 88 & $88(* * *)$ & 88 & 88 & $88(* * *)$ \\
\hline
\end{tabular}

Results from OLS regressions. Robust standard errors are in brackets. All regressions are in long-difference specifications with one observation per country. $* * *, * * *$ indicate significance at $1-, 5-$, and 10 -percent level, respectively. F-test refers to the test of joint significance of both human capital variables. 
Table 5: Robustness - Baseline Specification as in Cohen and Soto (2007) Extended Sample Period 1965-2005

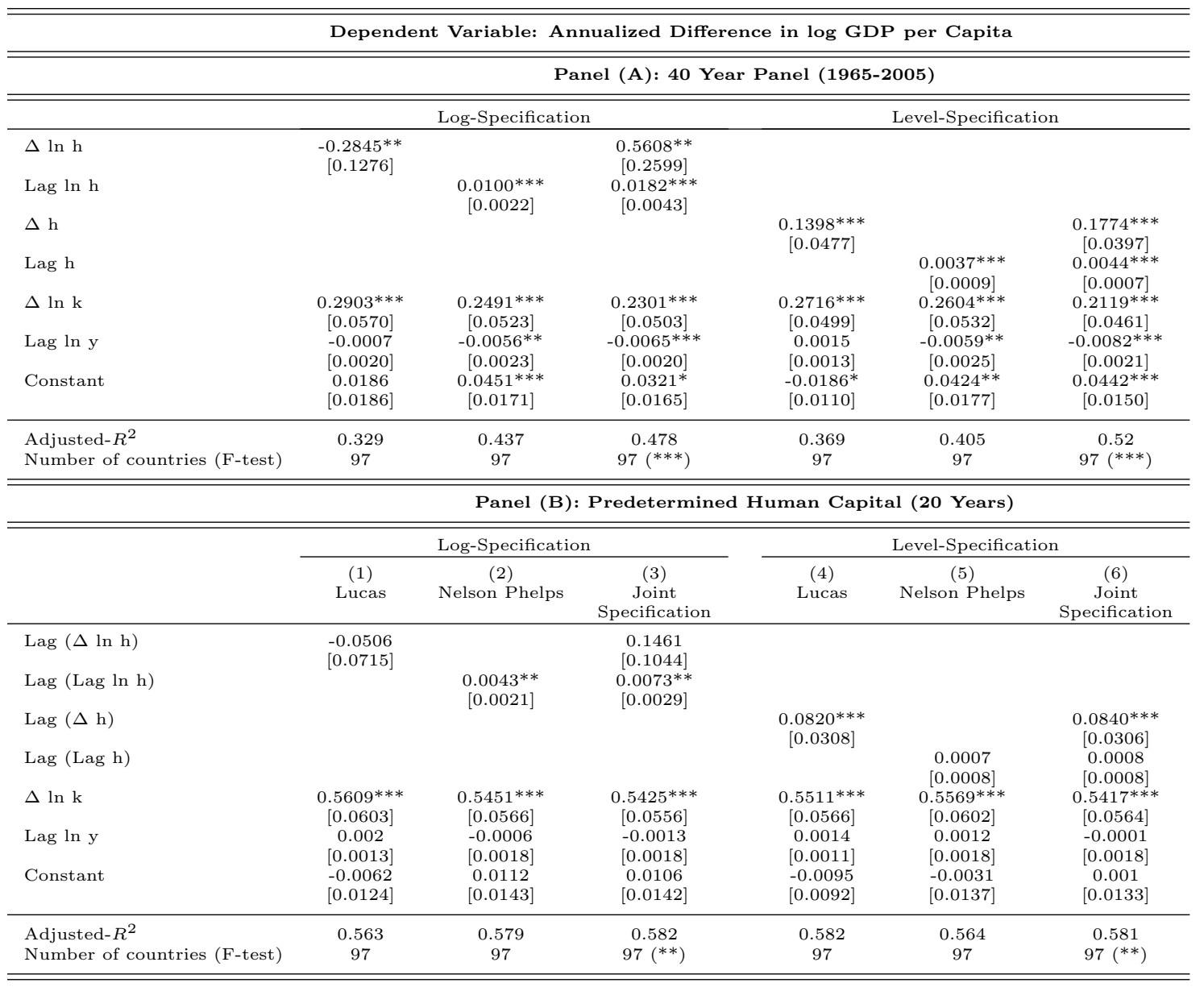

Results from OLS regressions. Robust standard errors are in brackets. All regressions are in long-difference specifications with one observation per country. Panel (B) estimates the model over the period 1985-2005, but uses the human capital variables from the period 1965-1985, i.e, changes in (log) human capital are measured 1965-1985 and initial (log) human capital is measured in 1965, respectively. $* * *, * *, *$ indicate significance at $1-, 5-$, and 10 -percent level, respectively. 
Table 6: Alternative Growth Regressions - Specification as in Benhabib and Spiegel

\begin{tabular}{|c|c|c|c|c|c|c|}
\hline & \multicolumn{6}{|c|}{ Dependent Variable: Annualized Difference in log GDP (1970-1990) } \\
\hline & \multicolumn{6}{|c|}{ Panel (A): Data from Cohen and Soto (2007) } \\
\hline & \multicolumn{3}{|c|}{ Log-Specification } & \multicolumn{3}{|c|}{ Level-Specification } \\
\hline & $(1)$ & $(2)$ & $(3)$ & $(4)$ & $(5)$ & $(6)$ \\
\hline$\Delta \operatorname{ln~h}$ & $\begin{array}{c}0.0846 \\
{[0.1040]}\end{array}$ & & $\begin{array}{c}0.2001 \\
{[0.1755]}\end{array}$ & & & \\
\hline Lag $\ln \mathrm{h}$ & & $\begin{array}{l}-0.0004 \\
{[0.0018]}\end{array}$ & $\begin{array}{c}0.0025 \\
{[0.0030]}\end{array}$ & & & \\
\hline$\Delta \mathrm{h}$ & & & & $\begin{array}{c}0.0357 \\
{[0.0487]}\end{array}$ & & $\begin{array}{c}0.0479 \\
{[0.0518]}\end{array}$ \\
\hline Lag h & & & & & $\begin{array}{l}-0.0003 \\
{[0.0006]}\end{array}$ & $\begin{array}{l}-0.0006 \\
{[0.0006]}\end{array}$ \\
\hline$\Delta \ln \mathrm{k}$ & $\begin{array}{c}0.4290^{* * *} * \\
{[0.0581]}\end{array}$ & $\begin{array}{c}0.4337^{* * *} * \\
{[0.0581]}\end{array}$ & $\begin{array}{c}0.4249 * * * \\
{[0.0578]}\end{array}$ & $\begin{array}{c}0.4182 * * * \\
{[0.0589]}\end{array}$ & $\begin{array}{c}0.4334^{* * *} * \\
{[0.0581]}\end{array}$ & $\begin{array}{c}0.4114^{* * *} * \\
{[0.0597]}\end{array}$ \\
\hline$\Delta \ln \mathrm{n}$ & $0.7003^{* * *}$ & $0.7286^{* * * *}$ & $0.6942^{* * *}$ & $0.7168^{* * *}$ & $0.6920^{* * *}$ & $0.6343^{* * *}$ \\
\hline Lag $\ln Y$ & $\begin{array}{c}{[0.1477]} \\
0.0005\end{array}$ & $\begin{array}{c}{[0.1507]} \\
0.0004\end{array}$ & $\begin{array}{c}{[0.1468]} \\
0.0002\end{array}$ & $\begin{array}{c}{[0.1500]} \\
0.0001\end{array}$ & $\begin{array}{c}{[0.1551]} \\
0.0005\end{array}$ & $\begin{array}{c}{[0.1522]} \\
0.0005\end{array}$ \\
\hline Lag in r & {$[0.0011]$} & {$[0.0011]$} & {$[0.0012]$} & {$[0.0010]$} & {$[0.0012]$} & {$[0.0012]$} \\
\hline Constant & -0.0025 & 0.0019 & -0.0026 & 0.0033 & 0.0011 & 0 \\
\hline & {$[0.0215]$} & {$[0.0205]$} & {$[0.0217]$} & {$[0.0182]$} & {$[0.0197]$} & [0.0198] \\
\hline Adjusted- $R^{2}$ & 0.546 & 0.541 & 0.545 & 0.546 & 0.542 & 0.545 \\
\hline \multirow[t]{4}{*}{ Number of countries (F-test) } & 81 & 81 & 81() & 81 & 81 & 81() \\
\hline & \multicolumn{6}{|c|}{ Panel (B): Data from Barro and Lee (2010) } \\
\hline & \multicolumn{3}{|c|}{ Log-Specification } & \multicolumn{3}{|c|}{ Level-Specification } \\
\hline & $(1)$ & $(2)$ & $(3)$ & $(4)$ & $(5)$ & $(6)$ \\
\hline$\Delta \ln \mathrm{h}$ & $\begin{array}{l}-0.0099 \\
{[0.0912]}\end{array}$ & & $\begin{array}{l}0.2862^{*} \\
{[0.1648]}\end{array}$ & & & \\
\hline Lag $\ln \mathrm{h}$ & & $\begin{array}{l}0.0035 * \\
{[0.0019]}\end{array}$ & $\begin{array}{c}0.0087^{* *} \\
{[0.0035]}\end{array}$ & & & \\
\hline$\Delta \mathrm{h}$ & & & & $\begin{array}{c}0.1158^{* *} \\
{[0.0443]}\end{array}$ & & $\begin{array}{c}0.1085^{* *} \\
{[0.0445]}\end{array}$ \\
\hline Lag h & & & & & $\begin{array}{l}0.0011^{*} \\
{[0.0006]}\end{array}$ & $\begin{array}{c}0.0007 \\
{[0.0006]}\end{array}$ \\
\hline$\Delta \operatorname{ln~k}$ & $\begin{array}{c}0.3805^{* * *} \\
{[0.0669]}\end{array}$ & $\begin{array}{c}0.3908^{* * *} * \\
{[0.0698]}\end{array}$ & $\begin{array}{c}0.3725 * * * \\
{[0.0653]}\end{array}$ & $\begin{array}{c}0.3464 * * * \\
{[0.0599]}\end{array}$ & $\begin{array}{c}0.3905^{* * *} * \\
{[0.0697]}\end{array}$ & $\begin{array}{c}0.3560^{* * *} * \\
{[0.0630]}\end{array}$ \\
\hline$\Delta \ln \mathrm{n}$ & $0.8419^{* * *}$ & $\begin{array}{c}0.9171^{* * *} \\
{[0.1616]}\end{array}$ & $\begin{array}{c}0.8623^{* * *} \\
{[0.1609]}\end{array}$ & $\begin{array}{l}0.7233^{* * *} \\
{[0.1543]}\end{array}$ & $\begin{array}{l}0.9573^{* * *} \\
{[0.1713]}\end{array}$ & $\begin{array}{l}0.8113^{* * *} \\
{[0.1618]}\end{array}$ \\
\hline Lag $\ln \mathrm{Y}$ & $\begin{array}{l}-0.0001 \\
{[0.0010]}\end{array}$ & $\begin{array}{l}-0.0008 \\
{[0.0011]}\end{array}$ & $\begin{array}{l}-0.0009 \\
0.0010]\end{array}$ & $\begin{array}{l}-0.0004 \\
{[0.0009]}\end{array}$ & $\begin{array}{l}-0.0007 \\
{[0.0011]}\end{array}$ & $\begin{array}{l}-0.0007 \\
{[0.0010]}\end{array}$ \\
\hline Constant & $\begin{array}{c}0.0035 \\
{[0.0180]}\end{array}$ & $\begin{array}{c}0.0096 \\
{[0.0177]}\end{array}$ & $\begin{array}{l}-0.0001 \\
{[0.0170]}\end{array}$ & $\begin{array}{c}0.0006 \\
{[0.0161]}\end{array}$ & $\begin{array}{c}0.0055 \\
{[0.0173]}\end{array}$ & $\begin{array}{c}0.0025 \\
{[0.0164]}\end{array}$ \\
\hline Adjusted- $R^{2}$ & 0.421 & 0.443 & 0.468 & 0.478 & 0.436 & 0.479 \\
\hline \multirow[t]{4}{*}{ Number of countries (F-test) } & 96 & 96 & $96(* *)$ & 96 & 96 & $96(* *)$ \\
\hline & \multicolumn{6}{|c|}{ Panel (C): Data from IIASA-VID (Lutz et al., 2007) } \\
\hline & \multicolumn{3}{|c|}{ Log-Specification } & \multicolumn{3}{|c|}{ Level-Specification } \\
\hline & $(1)$ & $(2)$ & $(3)$ & $(4)$ & $(5)$ & $(6)$ \\
\hline$\Delta \ln \mathrm{h}$ & $\begin{array}{l}-0.0735 \\
{[0.0803]}\end{array}$ & & $\begin{array}{c}0.4733^{* * *} * \\
{[0.1651]}\end{array}$ & & & \\
\hline Lag $\ln \mathrm{h}$ & & $\begin{array}{c}0.0036^{* *} \\
{[0.0016]}\end{array}$ & $\begin{array}{c}0.0123 * * * \\
{[0.0034]}\end{array}$ & & & \\
\hline$\Delta \mathrm{h}$ & & & & $\begin{array}{c}0.1335^{* * *} * \\
{[0.0322]}\end{array}$ & & $\begin{array}{c}0.1362^{* * *} \\
{[0.0309]}\end{array}$ \\
\hline Lag h & & & & & $\begin{array}{c}0.0007 \\
{[0.0005]}\end{array}$ & $\begin{array}{l}0.0008^{*} \\
{[0.0005]}\end{array}$ \\
\hline$\Delta \ln \mathrm{k}$ & $\begin{array}{c}0.3331 * * * \\
{[0.0541]}\end{array}$ & $\begin{array}{c}0.3409^{* * *} * \\
{[0.0543]}\end{array}$ & $\begin{array}{c}0.3460 * * * \\
{[0.0539]}\end{array}$ & $\begin{array}{c}0.3129 * * * \\
{[0.0511]}\end{array}$ & $\begin{array}{c}0.3370 * * * \\
{[0.0546]}\end{array}$ & $\begin{array}{c}0.3211^{* * *} * \\
{[0.0525]}\end{array}$ \\
\hline$\Delta \ln \mathrm{n}$ & $0.8261 * * *$ & $0.8434^{* * *}$ & $0.7646^{* * *}$ & $0.5357^{* * *}$ & $0.8748 * * *$ & $0.6234^{* * *}$ \\
\hline & {$[0.1596]$} & [0.1547] & [0.1401] & [0.1539] & {$[0.1686]$} & {$[0.1486]$} \\
\hline Lag $\ln \mathrm{Y}$ & 0.0001 & -0.0006 & -0.0007 & -0.0003 & 0.0001 & -0.0009 \\
\hline & {$[0.0010]$} & [0.0010] & [0.0010] & [0.0008] & {$[0.0009]$} & [0.0009] \\
\hline Constant & 0.0036 & 0.0091 & -0.0107 & 0.003 & -0.0016 & 0.0068 \\
\hline & {$[0.0198]$} & {$[0.0174]$} & {$[0.0209]$} & {$[0.0149]$} & {$[0.0168]$} & {$[0.0156]$} \\
\hline Adjusted- $R^{2}$ & 0.423 & 0.454 & 0.497 & 0.511 & 0.426 & 0.518 \\
\hline Number of countries (F-test) & 88 & 88 & $88(* * *)$ & 88 & 88 & $88(* * *)$ \\
\hline
\end{tabular}

Results from OLS regressions. Robust standard errors are in brackets. All regressions are in long-difference specifications with one observation per country. Panel $\mathrm{B}$ is reduced by one observation (Taiwan) due to lack of population data. $* * *, * * * *$ indicate significance at 1-, 5-, and 10-percent level, respectively. F-test refers to the test of joint significance of both human capital variables. 
Table 7: Robustness - Baseline Specification as in Benhabib-Spiegel (1994)

Extended Sample Period 1970-2000

\begin{tabular}{|c|c|c|c|c|c|c|}
\hline & \multicolumn{6}{|c|}{ Dependent Variable: Annualized Difference in log GDP (1970-2000) } \\
\hline & \multicolumn{6}{|c|}{ Panel (A): Data from Barro and Lee (2010) } \\
\hline & \multicolumn{3}{|c|}{ Log-Specification } & \multicolumn{3}{|c|}{ Level-Specification } \\
\hline & $(1)$ & $(2)$ & $(3)$ & $(4)$ & $(5)$ & $(6)$ \\
\hline$\Delta \ln \mathrm{h}$ & $\begin{array}{l}-0.0886 \\
{[0.0835]}\end{array}$ & & $\begin{array}{c}0.3011 * * \\
{[0.1458]}\end{array}$ & & & \\
\hline Lag $\ln \mathrm{h}$ & & $\begin{array}{c}0.0040 * * \\
{[0.0016]}\end{array}$ & $\begin{array}{c}0.0086^{* * *} * \\
{[0.0028]}\end{array}$ & & & \\
\hline$\Delta \mathrm{h}$ & & & & $\begin{array}{c}0.0787^{* *} \\
{[0.0323]}\end{array}$ & & $\begin{array}{c}0.0751^{* *} \\
{[0.0313]}\end{array}$ \\
\hline Lag h & & & & & $\begin{array}{c}0.0014^{* * *} \\
{[0.0005]}\end{array}$ & $\begin{array}{c}0.0014^{* * *} \\
{[0.0005]}\end{array}$ \\
\hline$\Delta \ln \mathrm{k}$ & $\begin{array}{c}0.4384 * * * \\
{[0.0667]}\end{array}$ & $\begin{array}{c}0.4381^{* * *} \\
{[0.0671]}\end{array}$ & $\begin{array}{c}0.4275^{* * *} \\
{[0.0635]}\end{array}$ & $\begin{array}{c}0.4117^{* * *} \\
{[0.0586]}\end{array}$ & $\begin{array}{c}0.4413^{* * *} \\
{[0.0668]}\end{array}$ & $\begin{array}{c}0.4198 * * * \\
{[0.0611]}\end{array}$ \\
\hline$\Delta \ln \mathrm{n}$ & $0.8883^{* * *}$ & $0.9476^{* * * *}$ & $0.8903^{* * *}$ & $0.7331^{* * *}$ & $1.0214^{* * *}$ & $0.9190^{* * *}$ \\
\hline 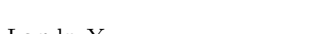 & {$[0.1553]$} & {$[0.1522]$} & [0.1499] & {$[0.1456]$} & {$[0.1607]$} & {$[0.1530]$} \\
\hline Lag $\ln \mathrm{Y}$ & -0.0003 & -0.0009 & -0.001 & -0.0003 & -0.0008 & -0.001 \\
\hline & {$[0.0008]$} & {$[0.0008]$} & {$[0.0007]$} & {$[0.0007]$} & {$[0.0008]$} & {$[0.0007]$} \\
\hline Constant & 0.0085 & 0.0104 & 0.0021 & 0.0031 & 0.006 & 0.0052 \\
\hline & {$[0.0147]$} & {$[0.0140]$} & {$[0.0139]$} & {$[0.0137]$} & {$[0.0138]$} & {$[0.0131]$} \\
\hline Adjusted- $R^{2}$ & 0.525 & 0.557 & 0.576 & 0.55 & 0.554 & 0.578 \\
\hline \multirow[t]{4}{*}{ Number of countries (F-test) } & 96 & 96 & $96(* * *)$ & 96 & 96 & $96(* * *)$ \\
\hline & \multicolumn{6}{|c|}{ Panel (B): Data from IIASA-VID (Lutz et al., 2007) } \\
\hline & \multicolumn{3}{|c|}{ Log-Specification } & \multicolumn{3}{|c|}{ Level-Specification } \\
\hline & $(1)$ & $(2)$ & $(3)$ & $(4)$ & $(5)$ & $(6)$ \\
\hline$\Delta \ln \mathrm{h}$ & $\begin{array}{c}-0.1200^{*} \\
{[0.0686]}\end{array}$ & & $\begin{array}{c}0.2935 \\
{[0.1864]}\end{array}$ & & & \\
\hline Lag $\ln \mathrm{h}$ & & $\begin{array}{c}0.0028^{* *} \\
{[0.0012]}\end{array}$ & $\begin{array}{c}0.0076^{* *} \\
{[0.0034]}\end{array}$ & & & \\
\hline$\Delta \mathrm{h}$ & & & & $\begin{array}{c}0.0746^{* * *} \\
{[0.0267]}\end{array}$ & & $\begin{array}{c}0.0814^{* * *} \\
{[0.0258]}\end{array}$ \\
\hline Lag h & & & & & $\begin{array}{c}0.0007 \\
{[0.0004]}\end{array}$ & $\begin{array}{c}0.0008^{* *} \\
{[0.0004]}\end{array}$ \\
\hline$\Delta \ln \mathrm{k}$ & $\begin{array}{c}0.4087^{* * *} \\
{[0.0601]}\end{array}$ & $\begin{array}{c}0.4084^{* * *} \\
{[0.0599]}\end{array}$ & $\begin{array}{c}0.4064^{* * *} \\
{[0.0592]}\end{array}$ & $\begin{array}{c}0.3860^{* * *} \\
{[0.0573]}\end{array}$ & $\begin{array}{c}0.4113 * * * \\
{[0.0601]}\end{array}$ & $\begin{array}{c}0.3895 * * * \\
{[0.0585]}\end{array}$ \\
\hline$\Delta \ln n$ & $0.7610^{* * *}$ & $0.7703^{* * *}$ & $0.7424^{* * *}$ & $0.5701^{* * *}$ & $0.8082 * * *$ & $0.6863^{* * *}$ \\
\hline & [0.1389] & [0.1402] & [0.1348] & [0.1409] & {$[0.1511]$} & [0.1433] \\
\hline Lag $\ln \mathrm{Y}$ & -0.0008 & -0.001 & -0.001 & -0.0006 & -0.0006 & -0.0011 \\
\hline & {$[0.0007]$} & {$[0.0007]$} & {$[0.0008]$} & {$[0.0007]$} & {$[0.0007]$} & {$[0.0007]$} \\
\hline Constant & 0.0216 & 0.0195 & 0.008 & 0.0126 & 0.0121 & 0.0144 \\
\hline & {$[0.0154]$} & [0.0138] & {$[0.0176]$} & {$[0.0135]$} & {$[0.0134]$} & {$[0.0134]$} \\
\hline Adjusted- $R^{2}$ & 0.527 & 0.542 & 0.548 & 0.545 & 0.523 & 0.559 \\
\hline Number of countries (F-test) & 88 & 88 & $88(* *)$ & 88 & 88 & $88(* * *)$ \\
\hline
\end{tabular}

Results from OLS regressions. Robust standard errors are in brackets. All regressions are in long-difference specifications with one Results from OLS regressions. Robust standard errors are in brackets. All regressions are in long-difference specifications with one lack of population data. ***, **,* indicate significance at 1-, 5-, and 10-percent level, respectively. F-test refers to the test of joint lack of population data. $* * *, * *, *$ indicate si
significance of both human capital variables. 
Table 8: Specification as in Mankiw, Romer and Weil (1992)

\begin{tabular}{|c|c|c|c|c|c|c|}
\hline & \multicolumn{6}{|c|}{ Data from Mankiw, Romer and Weil (1992) and Barro and Lee (2010) } \\
\hline & \multicolumn{6}{|c|}{ Panel (A): Log GDP per Worker in 1985} \\
\hline & \multicolumn{3}{|c|}{ Log-Specification } & \multicolumn{3}{|c|}{ Level-Specification } \\
\hline & $(1)$ & $(2)$ & $(3)$ & $(4)$ & $(5)$ & $(6)$ \\
\hline$\Delta \ln \mathrm{h}$ & $\begin{array}{c}-0.5691 * * * \\
{[0.1658]}\end{array}$ & & $\begin{array}{c}0.6341 * * \\
{[0.2622]}\end{array}$ & & & \\
\hline Lag $\ln \mathrm{h}$ & & $\begin{array}{c}0.5533^{* * *} \\
{[0.0793]}\end{array}$ & $\begin{array}{c}0.8284^{* * *} \\
{[0.1369]}\end{array}$ & & & \\
\hline$\Delta \mathrm{h}$ & & & & $\begin{array}{c}0.3030^{* * *} * \\
{[0.1009]}\end{array}$ & & $\begin{array}{c}0.2213^{* * *} \\
{[0.0766]}\end{array}$ \\
\hline Lag h & & & & & $\begin{array}{c}0.2352^{* * *} \\
{[0.0330]}\end{array}$ & $\begin{array}{c}0.2190 * * * \\
{[0.0290]}\end{array}$ \\
\hline $\ln (\mathrm{I} / \mathrm{GDP})$ & $\begin{array}{c}1.1257^{* * *} \\
{[0.1434]}\end{array}$ & $\begin{array}{c}0.6105^{* * *} * \\
{[0.1595]}\end{array}$ & $0.4992^{* * *}$ & $\begin{array}{c}1.1138 * * * \\
{[0.1781]}\end{array}$ & $0.7435 * * *$ & $0.6056^{* * *}$ \\
\hline $\ln (n+g+\delta)$ & $\begin{array}{c}-1.7588^{* * *} * \\
{[0.4969]}\end{array}$ & $\begin{array}{c}-1.2327^{* * * *} \\
{[0.4167]}\end{array}$ & $\begin{array}{c}-1.2098^{* * *} * \\
{[0.3850]}\end{array}$ & $\begin{array}{c}-2.2869^{* * *} \\
{[0.4894]}\end{array}$ & $\begin{array}{l}-0.4575 \\
{[0.4875]}\end{array}$ & $\begin{array}{l}-0.6764 \\
{[0.4342]}\end{array}$ \\
\hline Constant & $\begin{array}{c}8.8830^{* * * *} \\
{[1.1406]}\end{array}$ & $\begin{array}{c}8.5212^{* * * *} \\
{[0.9883]}\end{array}$ & $\begin{array}{c}8.1407^{* * * *} \\
{[0.9144]}\end{array}$ & $\begin{array}{c}8.9364^{* * *} \\
{[1.1804]}\end{array}$ & $\begin{array}{c}6.2735^{* * * *} \\
{[1.0359]}\end{array}$ & $\begin{array}{c}6.7066^{* * *} * \\
{[0.9620]}\end{array}$ \\
\hline Adjusted- $R^{2}$ & 0.625 & 0.738 & 0.759 & 0.625 & 0.736 & 0.761 \\
\hline \multirow[t]{4}{*}{ Number of countries (F-test) } & 91 & 91 & $91(* * *)$ & 91 & 91 & $91(* * *)$ \\
\hline & \multicolumn{6}{|c|}{ Panel (B): Difference in Log GDP per Worker (1960-1985) } \\
\hline & \multicolumn{3}{|c|}{ Log-Specification } & \multicolumn{3}{|c|}{ Level-Specification } \\
\hline & $(1)$ & $(2)$ & $(3)$ & $(4)$ & $(5)$ & $(6)$ \\
\hline$\Delta \ln \mathrm{h}$ & $\begin{array}{c}0.0519 \\
{[0.0862]}\end{array}$ & & $\begin{array}{l}0.3291 * \\
{[0.1670]}\end{array}$ & & & \\
\hline Lag $\ln \mathrm{h}$ & & $\begin{array}{c}0.0807 \\
{[0.0556]}\end{array}$ & $\begin{array}{c}0.2424^{* *} \\
{[0.0985]}\end{array}$ & & & \\
\hline$\Delta \mathrm{h}$ & & & & $\begin{array}{c}0.1161 * * \\
{[0.0518]}\end{array}$ & & $\begin{array}{c}0.1167^{* *} \\
{[0.0513]}\end{array}$ \\
\hline Lag h & & & & & $\begin{array}{c}0.0143 \\
{[0.0241]}\end{array}$ & $\begin{array}{c}0.016 \\
{[0.0233]}\end{array}$ \\
\hline $\ln (\mathrm{I} / \mathrm{GDP})$ & $\begin{array}{c}0.6197^{* * *} \\
{[0.1105]}\end{array}$ & $\begin{array}{c}0.5528^{* * *} \\
{[0.1164]}\end{array}$ & $\begin{array}{c}0.4974^{* * *} \\
{[0.1236]}\end{array}$ & $\begin{array}{c}0.5465^{* * *} \\
{[0.1184]}\end{array}$ & $\begin{array}{c}0.5954^{* * *} \\
{[0.1167]}\end{array}$ & $\begin{array}{c}0.5295^{* * *} * \\
{[0.1236]}\end{array}$ \\
\hline $\ln (n+g+\delta)$ & $\begin{array}{l}-0.3464 \\
{[0.2571]}\end{array}$ & $\begin{array}{l}-0.3319 \\
{[0.2478]}\end{array}$ & $\begin{array}{l}-0.3559 \\
{[0.2441]}\end{array}$ & $\begin{array}{c}-0.4680^{*} \\
{[0.2571]}\end{array}$ & $\begin{array}{l}-0.2917 \\
{[0.2555]}\end{array}$ & $\begin{array}{c}-0.4148^{*} \\
{[0.2472]}\end{array}$ \\
\hline Lag $\ln y$ & $\begin{array}{c}-0.1376^{* *} \\
{[0.0579]}\end{array}$ & $\begin{array}{c}-0.2100^{* * *} * \\
{[0.0635]}\end{array}$ & $\begin{array}{c}-0.2415 * * * \\
{[0.0589]}\end{array}$ & $\begin{array}{c}-0.1859^{* * *} \\
{[0.0496]}\end{array}$ & $\begin{array}{c}-0.1768^{* * *} * \\
{[0.0641]}\end{array}$ & $\begin{array}{c}-0.2147^{* * *} \\
{[0.0634]}\end{array}$ \\
\hline Constant & $\begin{array}{c}0.4521 \\
{[0.7849]}\end{array}$ & $\begin{array}{c}1.1542 \\
{[0.8055]}\end{array}$ & $\begin{array}{c}1.2508 \\
{[0.7948]}\end{array}$ & $\begin{array}{c}1.0791 \\
{[0.7468]}\end{array}$ & $\begin{array}{c}0.7098 \\
{[0.7571]}\end{array}$ & $\begin{array}{c}1.1943 \\
{[0.7915]}\end{array}$ \\
\hline Adjusted- $R^{2}$ & 0.337 & 0.347 & 0.378 & 0.38 & 0.337 & 0.375 \\
\hline Number of countries (F-test) & 91 & 91 & $91(*)$ & 91 & 91 & $91\left(^{*}\right)$ \\
\hline
\end{tabular}

Results from OLS regressions. Robust standard errors are in brackets. All regressions are in long-difference specifications with one observation per country. The regression in panel A replicates Table II of Mankiw, Romer and Weil (1992, P. 420). Panel B replicates Table V (P. 426). The main data is obtained from Greg Mankiw's homepage (http://www.economics.harvard.edu/faculty/mankiw/files/contr1.pdf), the human capital variables are constructed from Barro and (http://www. economics.harvard.edu/faculty/mankiw/files/contr1.pdf), the human capital variables are constructed from Barro and
Lee $(2010) . * * *, * *, *$ indicate significance at $1-, 5-$, and 10 -percent level, respectively. F-test refers to the test of joint significance of both human capital variables. 
Table 9: Specification as in Cohen and Soto (2007), Samples Without Outliers

\begin{tabular}{|c|c|c|c|c|c|c|}
\hline & Dependent & Variable: & Annualized 1 & erence in log & GDP per & pita (1970-1990) \\
\hline & \multicolumn{6}{|c|}{ Panel (A): Data from Cohen and Soto (2007) } \\
\hline & \multicolumn{3}{|c|}{ Log-Specification } & \multicolumn{3}{|c|}{ Level-Specification } \\
\hline & $(1)$ & $(2)$ & $(3)$ & $(4)$ & $(5)$ & (6) \\
\hline$\Delta \ln \mathrm{h}$ & $\begin{array}{l}-0.0372 \\
{[0.0700]}\end{array}$ & & $0.3452^{* * *}$ & & & \\
\hline Lag $\ln \mathrm{h}$ & & $\begin{array}{c}0.0054^{* * *} \\
{[0.0017]}\end{array}$ & $\begin{array}{c}0.0110^{* * *} \\
{[0.0029]}\end{array}$ & & & \\
\hline$\Delta \mathrm{h}$ & & & & $\begin{array}{c}0.1250^{* * *} \\
{[0.0245]}\end{array}$ & & $\begin{array}{c}0.1227^{* * *} \\
{[0.0217]}\end{array}$ \\
\hline Lag $\mathrm{h}$ & & & & & $\begin{array}{c}0.0017^{* * *} \\
{[0.0006]}\end{array}$ & $\begin{array}{c}0.0016^{* * *} \\
{[0.0005]}\end{array}$ \\
\hline$\Delta \ln \mathrm{k}$ & $0.5963^{* * *}$ & $0.5821^{* * *}$ & $0.5639^{* * *}$ & $0.5312^{* * *}$ & $0.5884^{* * *}$ & $0.5252^{* * *}$ \\
\hline & {$[0.0483]$} & {$[0.0440]$} & {$[0.0423]$} & {$[0.0443]$} & {$[0.0460]$} & [0.0439] \\
\hline Lag $\ln y$ & 0.0007 & $-0.0033^{*}$ & $-0.0045^{* *}$ & -0.0005 & -0.0032 & $-0.0046^{* *}$ \\
\hline & {$[0.0012]$} & {$[0.0019]$} & [0.0019] & {$[0.0011]$} & {$[0.0020]$} & [0.0018] \\
\hline Constant & -0.0077 & 0.0216 & 0.0171 & -0.0076 & 0.0186 & 0.0213 \\
\hline & {$[0.0122]$} & {$[0.0150]$} & {$[0.0136]$} & {$[0.0093]$} & {$[0.0159]$} & {$[0.0131]$} \\
\hline Adjusted- $R^{2}$ & 0.713 & 0.747 & 0.772 & 0.776 & 0.736 & 0.794 \\
\hline \multirow[t]{4}{*}{ Number of countries (F-test) } & 73 & 73 & $73(* * *)$ & 73 & 73 & $73(* * *)$ \\
\hline & \multicolumn{6}{|c|}{ Panel (B): Data from Barro and Lee (2010) } \\
\hline & \multicolumn{3}{|c|}{ Log-Specification } & \multicolumn{3}{|c|}{ Level-Specification } \\
\hline & $(1)$ & $(2)$ & $(3)$ & $(4)$ & $(5)$ & (6) \\
\hline$\Delta \ln \mathrm{h}$ & $\begin{array}{l}-0.1387 \\
{[0.1077]}\end{array}$ & & $\begin{array}{l}0.2250 * \\
{[0.1309]}\end{array}$ & & & \\
\hline Lag $\ln \mathrm{h}$ & & $\begin{array}{c}0.0091^{* * *} \\
{[0.0029]}\end{array}$ & $\begin{array}{c}0.0138^{* * *} \\
{[0.0032]}\end{array}$ & & & \\
\hline$\Delta \mathrm{h}$ & & & & $\begin{array}{c}0.1128^{* * *} \\
{[0.0377]}\end{array}$ & & $\begin{array}{c}0.1204^{* * *} \\
{[0.0356]}\end{array}$ \\
\hline Lag h & & & & & $\begin{array}{l}0.0021^{* *} \\
{[0.0009]}\end{array}$ & $\begin{array}{c}0.0023^{* * *} \\
{[0.0008]}\end{array}$ \\
\hline$\Delta \ln \mathrm{k}$ & $\begin{array}{l}0.4782^{* * *} \\
{[0.0649]}\end{array}$ & $\begin{array}{l}0.4570^{* * *} \\
{[0.0591]}\end{array}$ & $\begin{array}{l}0.4413^{* * *} \\
{[0.0606]}\end{array}$ & $\begin{array}{l}0.4272 * * * \\
{[0.0620]}\end{array}$ & $\begin{array}{l}0.4387^{* * *} \\
{[0.0641]}\end{array}$ & $\begin{array}{l}0.4027^{* * *} \\
{[0.0609]}\end{array}$ \\
\hline Lag $\ln y$ & 0.0028 & -0.0023 & -0.0032 & $0.0039^{* * *}$ & 0.0002 & -0.0014 \\
\hline Constant & $\begin{array}{l}{[0.0020]} \\
-0.0208\end{array}$ & $\begin{array}{c}{[0.0026]} \\
0.0096\end{array}$ & $\begin{array}{c}{[0.0024]} \\
0.0058\end{array}$ & $\begin{array}{c}{[0.0014]} \\
-0.0430 * * *\end{array}$ & $\begin{array}{c}{[0.0026]} \\
-0.0098\end{array}$ & $\begin{array}{l}{[0.0024]} \\
-0.0077\end{array}$ \\
\hline Constant & {$[0.0201]$} & {$[0.0195]$} & {$[0.0193]$} & $\begin{array}{c}-0.0430 \\
{[0.0121]}\end{array}$ & {$[0.0194]$} & {$[0.0181]$} \\
\hline Adjusted- $R^{2}$ & 0.494 & 0.569 & 0.585 & 0.548 & 0.519 & 0.582 \\
\hline \multirow[t]{4}{*}{ Number of countries (F-test) } & 87 & 87 & $87(* * *)$ & 87 & 87 & $87(* * *)$ \\
\hline & \multicolumn{6}{|c|}{ Panel (C): Data from VID-IIASA (Lutz et al., 2007) } \\
\hline & \multicolumn{3}{|c|}{ Log-Specification } & \multicolumn{3}{|c|}{ Level-Specification } \\
\hline & $(1)$ & $(2)$ & $(3)$ & $(4)$ & $(5)$ & $(6)$ \\
\hline$\Delta \ln \mathrm{h}$ & $\begin{array}{c}-0.1441^{*} \\
{[0.0796]}\end{array}$ & & $\begin{array}{c}0.6495^{* * *} \\
{[0.1630]}\end{array}$ & & & \\
\hline Lag $\ln \mathrm{h}$ & & $\begin{array}{c}0.0068^{* * *} \\
{[0.0018]}\end{array}$ & $\begin{array}{c}0.0201 * * * \\
{[0.0039]}\end{array}$ & & & \\
\hline$\Delta \mathrm{h}$ & & & & $\begin{array}{c}0.1531 * * * \\
{[0.0327]}\end{array}$ & & $\begin{array}{c}0.1892 * * * \\
{[0.0280]}\end{array}$ \\
\hline Lag h & & & & & $\begin{array}{l}0.0013^{*} \\
{[0.0007]}\end{array}$ & $\begin{array}{c}0.0026^{* * *} \\
{[0.0006]}\end{array}$ \\
\hline$\Delta \ln \mathrm{k}$ & $\begin{array}{c}0.3949 * * * \\
{[0.0646]}\end{array}$ & $\begin{array}{c}0.3895^{* * *} \\
{[0.0571]}\end{array}$ & $\begin{array}{c}0.4072^{* * *} \\
{[0.0497]}\end{array}$ & $\begin{array}{c}0.3670^{* * *} \\
{[0.0459]}\end{array}$ & $\begin{array}{c}0.3856^{* * *} \\
{[0.0609]}\end{array}$ & $\begin{array}{c}0.3485^{* * *} \\
{[0.0415]}\end{array}$ \\
\hline Lag $\ln y$ & $0.0034^{*}$ & 0.0001 & -0.0016 & $0.0044^{* * *}$ & 0.0019 & -0.0021 \\
\hline & {$[0.0019]$} & {$[0.0021]$} & {$[0.0019]$} & {$[0.0014]$} & {$[0.0024]$} & {$[0.0021]$} \\
\hline Constant & -0.0232 & -0.0063 & $-0.0267^{*}$ & $-0.0494 * * *$ & -0.0196 & -0.0086 \\
\hline & {$[0.0178]$} & {$[0.0159]$} & {$[0.0143]$} & {$[0.0111]$} & {$[0.0180]$} & {$[0.0144]$} \\
\hline Adjusted- $R^{2}$ & 0.45 & 0.527 & 0.614 & 0.551 & 0.414 & 0.629 \\
\hline Number of countries (F-test) & 79 & 79 & $79(* * *)$ & 79 & 79 & $79(* * *)$ \\
\hline
\end{tabular}

Results from OLS regressions. Robust standard errors are in brackets. All regressions are in long-difference specifications with one observation per country. Panel $\mathrm{A}$ and $\mathrm{B}$ are reduced by $5 \%$ of the top and bottom outliers, respectively. The Log-Specification in Panel $\mathrm{C}$ is reduced by the lowest 4 and highest 5 ros the lowest 5 and highest 4 residual observations (total of $10 \%$ ). See text for details. ${ }^{* *}, * *, *$ indicate significance at $1-, 5-$, and 10-percent level, respectively. F-test refers to the test of joint significance of both human capital variables. 


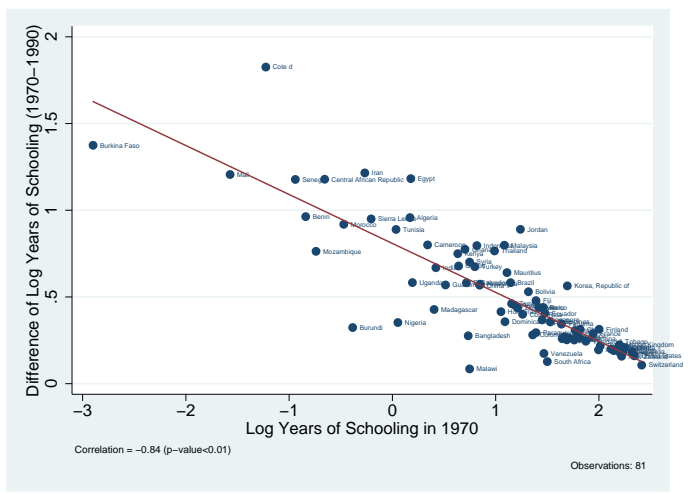

(a) Convergence in Log Average Schooling 19701990: Cohen and Soto (2007)

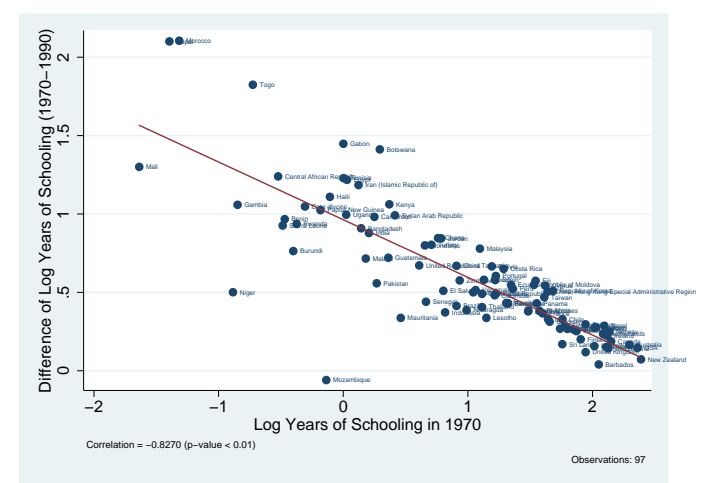

(b) Convergence in Log Average Schooling 19701990: Barro and Lee (2010)

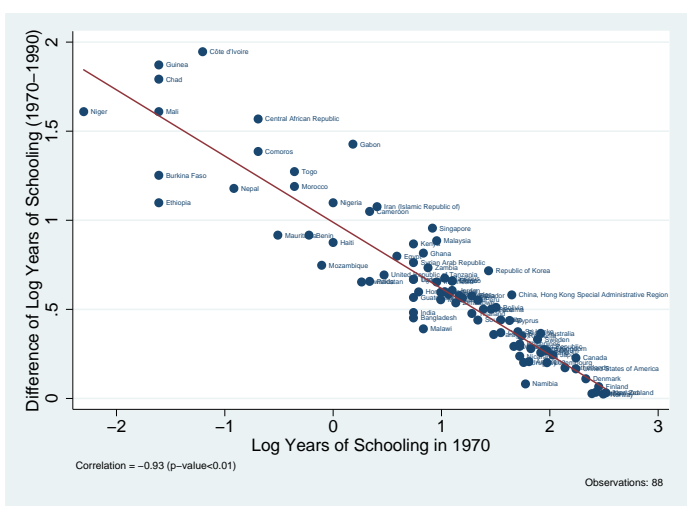

(c) Convergence in Log Average Schooling 19701990: IIASA-VID (2007)

Figure 1: The Relation Between Initial Human Capital and Changes in Human Capital in Different Data Sets (1970-1990) 


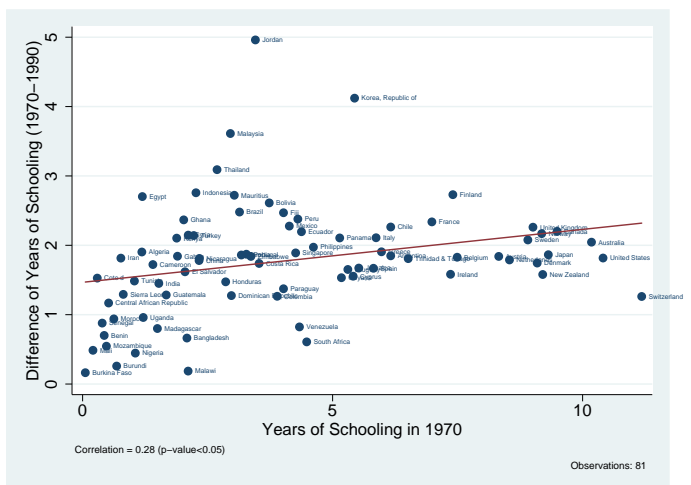

(a) Convergence in Average Schooling 1970-1990: Cohen and Soto (2007)

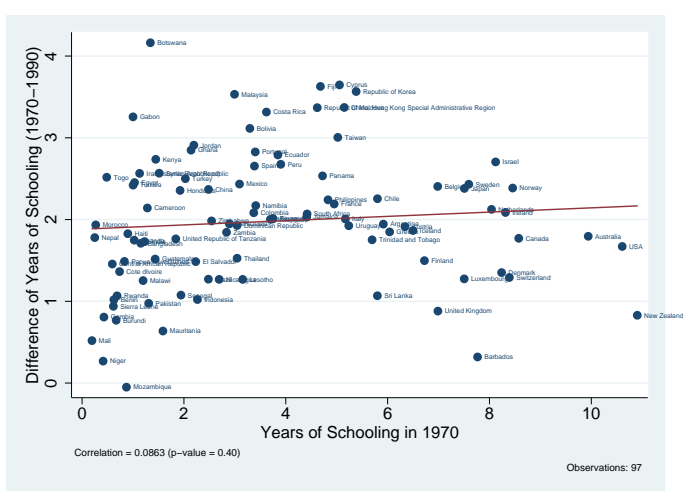

(b) Convergence in Average Schooling 1970-1990: Barro and Lee (2010)

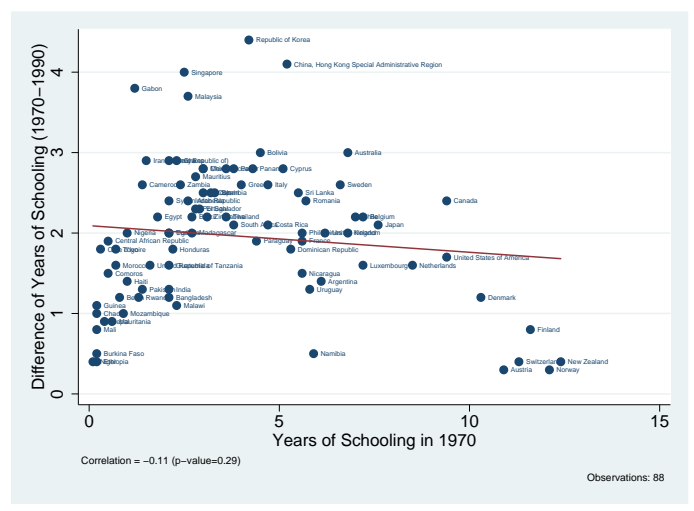

(c) Convergence in Average Schooling 1970-1990: IIASA-VID (2007)

Figure 2: The Relation Between Initial Human Capital and Changes in Human Capital in Different Data Sets (1970-1990) 

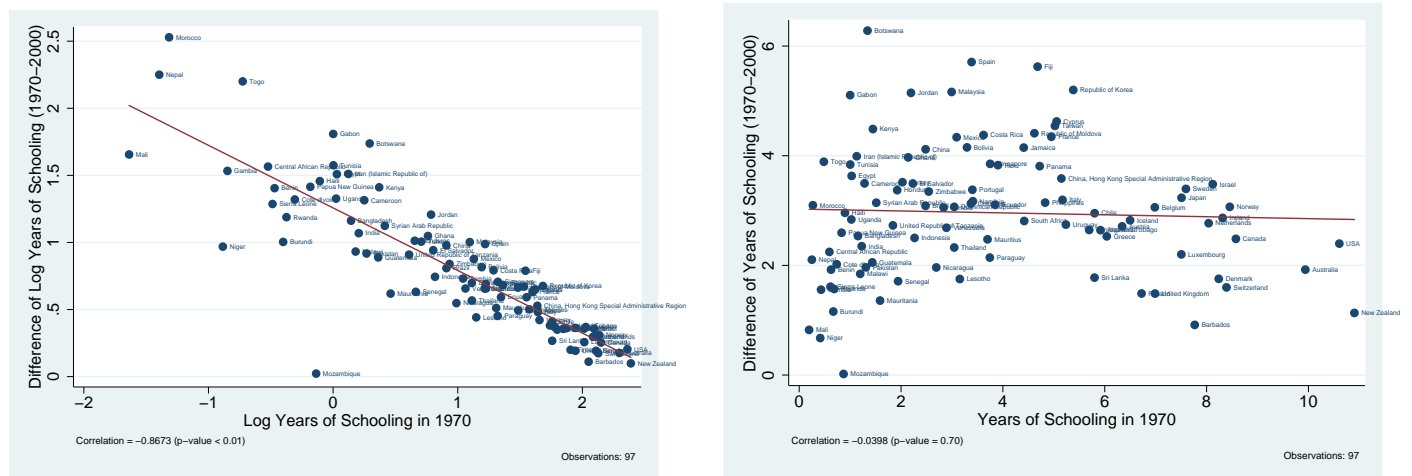

(a) Convergence in Log Average Schooling 1970- (b) Convergence in Average Schooling 1970-2000: 2000: Barro and Lee (2010) Barro and Lee (2010)
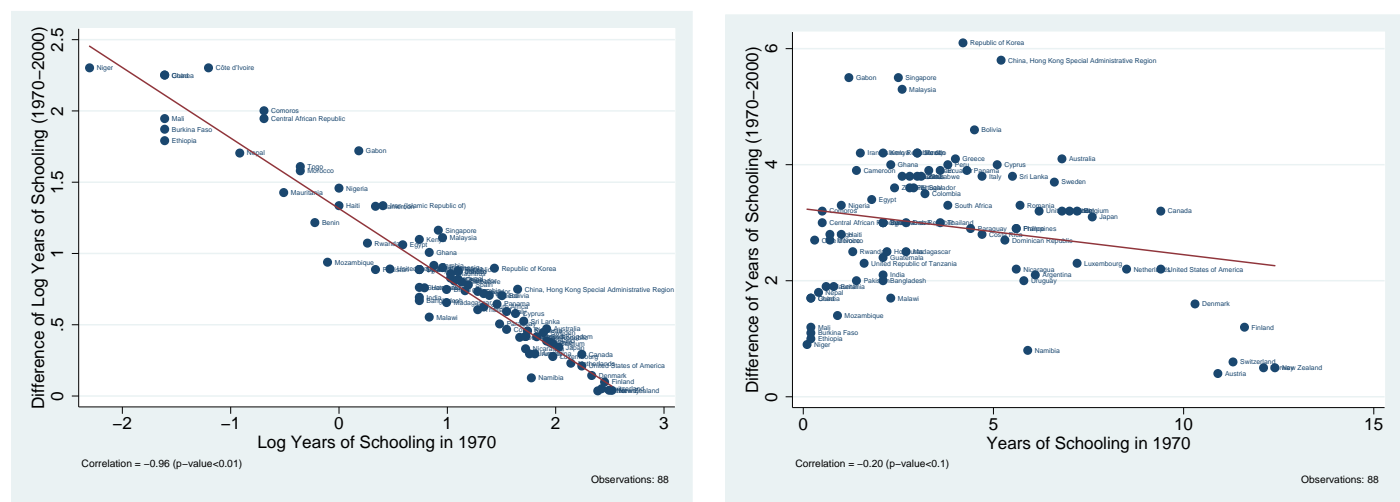

(c) Convergence in Log Average Schooling 1970- (d) Convergence in Average Schooling 1970-2000: 2000: IIASA-VID (2007) IIASA-VID (2007)

Figure 3: The Relation Between Initial Human Capital and Changes in Human Capital in Different Data Sets (1970-2000) 